\title{
Improved Hydrological Modelling of Urban Catchments Using Runoff Coefficients
}

\author{
Stephen J Birkinshaw ${ }^{1}$, Greg O’Donnell ${ }^{1}$, Vassilis Glenis ${ }^{1}$, Chris Kilsby ${ }^{1}$ \\ 1. School of Engineering, Newcastle University, Newcastle upon Tyne, NE1 7RU, UK
}

\begin{abstract}
The expansion of built-up areas within urban and peri-urban river catchments has the potential to increase flooding. Hydrological modelling of these catchments is an important tool to analyse and manage the increasing flood hazard, but it requires an understanding of the areas contributing to runoff from the urban parts of the catchment. This is difficult as in many catchments fine resolution data is not available and the connectivity of the impervious areas, sewer networks and the drainage network are not well understood. In this research, we present a novel approach for calculating the separate and combined sewer fractions for an urban river catchment and use these fractions to improve hydrological modelling of the catchment. The fractions are calculated using monthly runoff coefficients from paired rural/urban catchments, with the procedure carried out for 20 highly urbanized catchments within the UK. The calculated fractions have been compared with the OS MasterMap high-resolution land use data set and also verified against results obtained with the standard method of using hourly rainfall-runoff data in an event-based approach. Hydrological modelling using the physically-based Shetran system demonstrates improved results using the approach developed here. For urban and peri-urban catchments without fine resolution sewer and hydrological data, it is recommended that this new method should be applied before detailed hydrological modelling of the catchments is undertaken in order to evaluate the flows to the drainage network and determine the impact of urbanisation on the water balance.
\end{abstract}

\section{Highlights}

- Separate and combined sewer fractions are calculated for urban catchments

- Method requires monthly rainfall-runoff data from paired rural/urban catchments

- Verification against more data intensive methods shows good agreement

- Hydrological modelling using the novel approach shows improved results

- Results demonstrate the impact of urbanisation on the catchment water balance 


\section{Keywords}

Urban drainage; Effective impervious area; Runoff coefficients; Sewer systems; Paired rural/urban catchment; Hydrological modelling

\section{Introduction}

Currently around 55\% of the world's population is living in urban areas, a proportion that is expected to increase to $68 \%$ by 2050 (United Nations, 2019). The impacts of urbanization on water quantity and quality are well documented (e.g. Arnold and Gibbons, 1996; Jacobson, 2011; Miller and Hutchins, 2017, Oudin et al., 2018). Regarding water quantity, a main concern with urban expansion is reduced time to peak (flashiness), enhanced peak flows and increased runoff volumes (e.g. McMahon et al., 2003, Miller et al., 2014). For water quality, the main issue is the increased mobilisation and transport of contaminants into receiving waters (McGrane, 2016; de Mello et al., 2018; Salerno et al., 2018). Understanding and managing the hydrology of highly urbanized catchments is complicated by the role of the sewer network and its linkages to impervious areas and water courses. Separate storm sewer systems contribute runoff directly into watercourses, while combined storm and sewerage water systems feed into water treatment works, which are in many cases located outside the catchment.

Hydrological modelling in an urban environment is an important tool in understanding the increasing flood risk and to manage flood hazards, for example, understanding the benefits of the use of green infrastructure in urban areas (Ellis, 2013; Epps and Hathaway, 2018, O'Donnell et al., 2020). However, the modelling is challenging due to the highly heterogeneous nature of urban catchments and specific hydrological processes such as the sewer network. Effective modelling requires not only a measure of the impervious areas but also an understanding of the connectivity of impervious areas, the sewer systems and the drainage network. For an individual building, road or car park it is possible to measure the proportion of the precipitation that lands on impervious areas which enters the sewer network (Lee and Heaney, 2003). However, the patchwork of green and built-up areas complicates analyses when considering the larger scale (Alberti et al., 2007; Seo et al., 2013). Impervious areas such as roads, buildings and car parks contribute flow to the sewer system but may also drain into adjacent pervious green areas. Gardens are predominantly pervious and allow infiltration, but may have impervious and drained sections (Warhurst et al., 2014; Kelly, 2018). Two widely used terms in urban hydrology that consider these issues of impervious area and hydraulic 
connectivity are the Total Impervious Area (TIA) and the Effective Impervious Area (EIA). These terms are defined below and are used in the verification of the approach developed in this work.

The Total Impervious Area (TIA) is the impervious area as a fraction of the total catchment area (O'Driscoll et al.,2010; McGrane, 2016). There is no standard methodology to calculate TIA, with a number of techniques utilized including ground mapping and the classification of satellite data. Consequently, the comparison of results between studies is difficult (e.g. Slonecker and Tilley, 2004). Another shortcoming of TIA for water quantity and quality management issues is that it does not distinguish between impervious areas that are hydraulically connected to the sewer system/drainage network, and those which drain into pervious areas (Lee and Heaney, 2003; Shuster et al., 2005; Roy and Shuster, 2009; Burns et al., 2015; Ebrahimian et al., 2016b).

The Effective Impervious Area (EIA) is defined as the impervious area that is hydraulically connected to the sewer system/drainage network as a fraction of the total catchment area, so it is an important value in determining the actual runoff (Boyd, et al., 1993; Jones et al., 2003; Ebrahimian et al., 2016a). The EIA is usually calculated from an analysis of the event-based rainfall-runoff response (Ebrahimian et al., 2016a), although alternative methods are used (Jones et al., 2003; Han and Burian, 2009; Epps and Hathaway, 2018). Jacobsen (2011), Miller et al. (2014) and Ebrahimian et al. (2016a) have compared EIA and TIA values and found significant variation depending on local factors including the storm drainage network and flood attenuation features. McGrane (2016), Janke et al. (2011) and Fletcher et al. (2013) have all highlighted that quantifying the EIA is a research goal in urban hydrology.

This work focuses on the hydrological modelling of catchments that contain urban, peri-urban and rural areas (Fletcher et al. 2013, Salvadore et al. 2015; Hutchins et al., 2017). In distributed or semidistributed hydrological models of urban and peri-urban areas the catchments are generally split into a pervious fraction, that takes into account the higher infiltration and delayed runoff in the 'green areas' within the catchment, and an impervious fraction, which accounts for the reduced infiltration and faster runoff in the 'built-up' areas. Examples include the SWAT model (Sisay et al. 2017), the DHSVM model (Cuo et al. 2008) and the VIC model (Yang et al. 2011). Coupled hydrological/hydraulic models, that may be applied to small catchment areas, incorporate detailed knowledge of the storm drainage network. Examples include SWMM (Palla and Gnecco, 2015), MIKE URBAN (Bisht et al., 2016) and CityCAT (Glenis et al., 2018). However, in many cases there is no information on the storm drainage network, in which case simpler models are used (Coutu et al. 2012; Petrucci and Bonhomme, 2014). In order to understand the flow pathways, as well as incorporating impervious area, it is important to establish the fraction of water that flows into 
combined sewers, which is removed from and treated outside the catchment, and separate sewers, where the water flows directly into the channel drainage network and to the catchment outlet (Vrebos et al. 2014).

In this work the following key fractions of a catchment from a hydrological modelling viewpoint are defined:

a) The separate sewer fraction $\left(F_{s}\right)$. Runoff generated in fraction $F_{s}$ reaches the catchment outlet via impervious areas and the sewer system/drainage network. This corresponds to the EIA.

b) The combined sewer fraction $\left(F_{c}\right)$. Runoff generated in fraction $F_{c}$ flows into the combined sewer system which is removed and treated outside the catchment.

c) The pervious fraction $\left(F_{p}\right)$. Runoff generated in fraction $F_{p}$ reaches the catchments outlet by typical 'green area' pathways including subsurface flow and channel-aquifer interactions.

The three key objectives in this work are:

- Develop a novel approach which uses monthly rainfall-runoff records from paired rural/urban catchments to provide estimates of the three fractions $\left(F_{s}, F_{c}\right.$, and $\left.F_{p}\right)$. The approach is applied to 20 urbanized catchments in the UK.

- Verify the three fractions $\left(F_{s,} F_{c}\right.$, and $\left.F_{p}\right)$. For each of the 20 catchments compare the values $\left(F_{s}+F_{c}\right)$ with TIA values calculated using standard land-use classifications, two of which use fine resolution ground mapping and one using satellite data. Also for nine catchments, compare $F_{s}$ against those calculated using the more data intensive event-based rainfallrunoff response method.

- Conduct a hydrological modelling study for three of the 20 catchments using the $F_{s}, F_{c}$ and $F_{p}$ fractions calculated here and additionally using standard approaches. This study is intended to demonstrate the importance of using the correct separate and combined fractions within hydrological models.

These three objectives can be seen on the overall flow chart of the work (Fig. 1). 


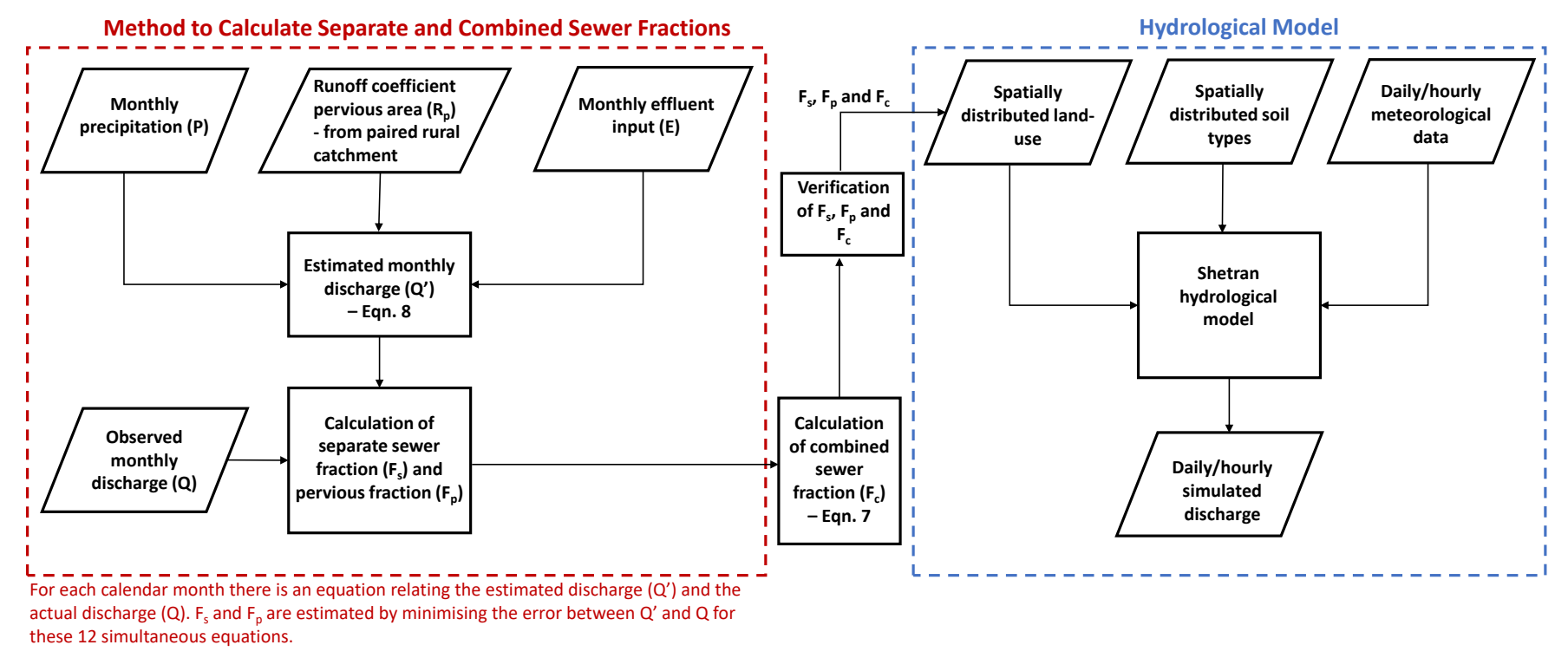

Fig. 1. Flow chart showing the overall methodology of the research

\section{Data and methods}

\subsection{Catchment selection}

The choice of UK catchments for inclusion in this study was firstly determined by the availability of 25 years of concurrent monthly precipitation and flow records. Although there is no strict distinction between rural and urban catchments, research (e.g. Booth and Jackson, 1997) suggests a $10 \%$ impervious area can have a significant impact on the water mass balance. Here, rural catchments were specified as having an impervious cover of less than $8 \%$, and with no concentrated settlements, and urban catchments greater than $14 \%$. (The OS MasterMap data set was used to define these percentages, see Section 2.3).

Catchments were excluded where significant transfers of surface water or groundwater abstractions were reported by the UK National River Flow Archive (NRFA). To reduce heterogeneity when selecting rural/urban catchment pairs, the catchment outfalls were required to be within $80 \mathrm{~km}$, the difference in mean annual precipitation less than $15 \%$ and the Base Flow Index (BFI) values (Gustard et al. 1992) within 0.15. Using these selection criteria, 20 urban and 5 rural catchments were identified, which were clustered around 5 separate urban conurbations and ranged in area from $9.9 \mathrm{~km}^{2}$ to $405.6 \mathrm{~km}^{2}$ (Fig. 2 and Table 1 ).

To provide a demonstration of the approach, the Ouseburn catchment (Newcastle upon Tyne) is considered as a case study (Fig. 3). Situated on the Ouseburn river are the nested "rural" gauge at 
Woolsington $\left(11.4 \mathrm{~km}^{2}\right)$ and the downstream "urban" gauge at Crag Hall $\left(53.8 \mathrm{~km}^{2}\right)$. (Note, this is the only pair of nested rural/urban catchments included in the study.) Digital maps of the sewer network within the Ouseburn catchment are available (Newcastle City Council, 2015), which are used in the verify the estimates of the separate and combined sewer fractions (Section 4.3). The Ouseburn is also included as part of the hydrological modelling study that shows the importance of using the correct combined and separate sewer fractions.
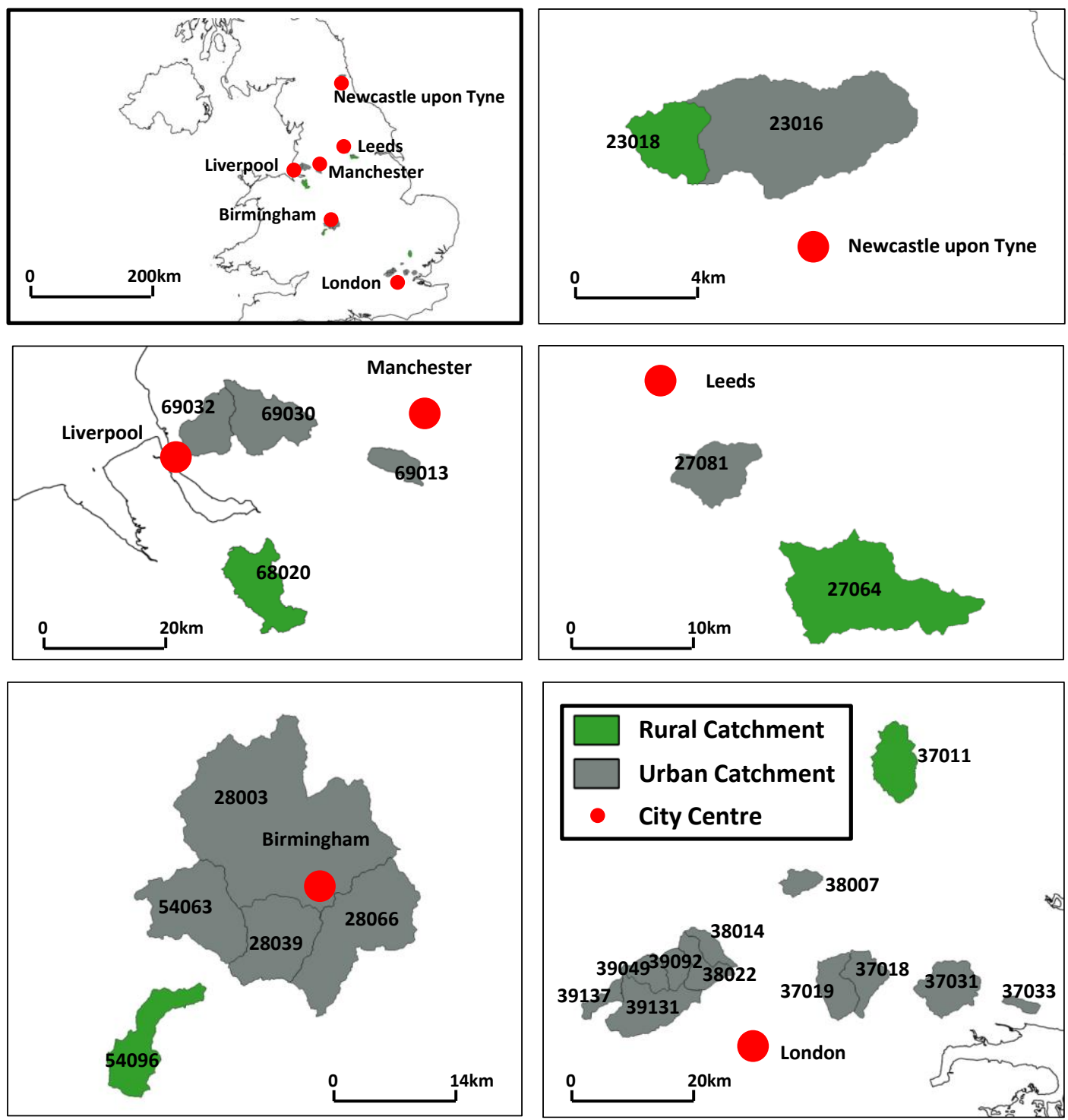

Fig. 2. Location of the selected 20 urban and five rural catchments within the UK 
Table 1. The selected five rural and 20 urban UK catchments, separated out in relation to the nearest urban conurbation. Rural catchments in bold. For LCM 2007 and OSMM see Section 2.3 and for Effluent inputs see Section 3.1

\begin{tabular}{|c|c|c|c|c|c|c|c|c|c|c|c|c|}
\hline \multirow[b]{2}{*}{ Nearest city } & \multirow[b]{2}{*}{$\begin{array}{c}\text { Catchment } \\
\text { number }\end{array}$} & \multirow[b]{2}{*}{ Catchment name } & \multirow[b]{2}{*}{ Area $\left(\mathrm{km}^{2}\right)$} & \multirow[b]{2}{*}{$\begin{array}{c}\text { Annual } \\
\text { precipitation } \\
(\mathrm{mm})\end{array}$} & \multirow[b]{2}{*}{$\begin{array}{c}\text { Effluent } \\
\text { inputs } \\
\text { (mm/year) }\end{array}$} & \multicolumn{3}{|c|}{ Total Impervious Area (TIA) } & \multirow[b]{2}{*}{$\begin{array}{c}\text { Separate } \\
\text { sewer } \\
\text { fraction, } \\
\text { Fs }_{\mathrm{s}}\end{array}$} & \multirow[b]{2}{*}{$\begin{array}{c}\text { Combined } \\
\text { sewer } \\
\text { fraction, } \\
F_{c}\end{array}$} & \multirow[b]{2}{*}{$\begin{array}{c}\text { Pervious } \\
\text { fraction, } \\
F_{p}\end{array}$} & \multirow{2}{*}{$\begin{array}{c}\text { Separate } \\
\text { sewer } \\
\text { fraction, } F_{s}- \\
\text { event based } \\
\text { approach }\end{array}$} \\
\hline & & & & & & LCM 2007 & OSMM & $\begin{array}{l}\text { OSMM+ } \\
\text { (inc. } \\
\text { gardens) }\end{array}$ & & & & \\
\hline \multirow[t]{5}{*}{ Birmingham } & 54096 & $\begin{array}{l}\text { Hadley Brook at } \\
\text { Wards Bridge }\end{array}$ & 54.0 & 699 & 0 & 0.02 & 0.04 & 0.08 & & & & \\
\hline & 28003 & $\begin{array}{l}\text { Tame at Water } \\
\text { Orton }\end{array}$ & 405.6 & 766 & 110 & 0.48 & 0.37 & 0.64 & 0.27 & 0.32 & 0.41 & 0.24 \\
\hline & 28039 & $\begin{array}{l}\text { Rea at Calthorpe } \\
\text { Park }\end{array}$ & 73.9 & 808 & 49 & 0.41 & 0.32 & 0.63 & 0.18 & 0.27 & 0.55 & 0.20 \\
\hline & 28066 & Cole at Coleshill & 119.6 & 737 & 24 & 0.36 & 0.30 & 0.59 & 0.16 & 0.27 & 0.57 & 0.17 \\
\hline & 54063 & $\begin{array}{l}\text { Stour at Prestwood } \\
\text { Hospital }\end{array}$ & 89.2 & 747 & 73 & 0.35 & 0.28 & 0.52 & 0.24 & 0.25 & 0.51 & \\
\hline \multirow[t]{2}{*}{ Leeds } & 27064 & $\begin{array}{l}\text { Went at Walden } \\
\text { Stubbs }\end{array}$ & 86.3 & 618 & 15 & 0.05 & 0.07 & 0.09 & & & & \\
\hline & 27081 & $\begin{array}{l}\text { Oulton Beck at } \\
\text { Farrer Lane }\end{array}$ & 25.1 & 662 & 0 & 0.22 & 0.21 & 0.36 & 0.11 & 0.24 & 0.65 & 0.11 \\
\hline \multirow[t]{5}{*}{ London } & 37011 & $\begin{array}{l}\text { Chelmer at } \\
\text { Churchend }\end{array}$ & 72.8 & 627 & 0 & 0.01 & 0.03 & 0.06 & & & & \\
\hline & 37018 & $\begin{array}{l}\text { Ingrebourne at } \\
\text { Gaynes Park }\end{array}$ & 44.8 & 608 & 36 & 0.16 & 0.14 & 0.27 & 0.12 & 0.0 & 0.88 & \\
\hline & 37019 & $\begin{array}{l}\text { Beam at Bretons } \\
\text { Farm }\end{array}$ & 51.5 & 602 & 36 & 0.31 & 0.24 & 0.48 & 0.13 & 0.19 & 0.68 & \\
\hline & 37031 & Crouch at Wickford & 70.2 & 589 & 6 & 0.24 & 0.20 & 0.36 & 0.11 & 0.21 & 0.68 & 0.12 \\
\hline & 37033 & $\begin{array}{l}\text { Eastwood Brook at } \\
\text { Eastwood }\end{array}$ & 9.9 & 573 & 10 & 0.39 & 0.31 & 0.67 & 0.22 & 0.37 & 0.41 & 0.18 \\
\hline
\end{tabular}




\begin{tabular}{|c|c|c|c|c|c|c|c|c|c|c|c|c|}
\hline & 38007 & $\begin{array}{l}\text { Canons Brook at } \\
\text { Elizabeth Way }\end{array}$ & 20.7 & 621 & 0 & 0.27 & 0.26 & 0.44 & 0.29 & 0.01 & 0.70 & \\
\hline & 38014 & $\begin{array}{l}\text { Salmon Brook at } \\
\text { Edmonton }\end{array}$ & 22.8 & 668 & 0 & 0.22 & 0.18 & 0.38 & 0.14 & 0.01 & 0.85 & \\
\hline & 38022 & $\begin{array}{l}\text { Pymmes Brook at } \\
\text { Edmonton Silver } \\
\text { Street }\end{array}$ & 40.5 & 675 & 0 & 0.45 & 0.35 & 0.68 & 0.41 & 0.01 & 0.58 & \\
\hline & 39049 & $\begin{array}{l}\text { Silk Stream at } \\
\text { Colindeep Lane }\end{array}$ & 30.8 & 689 & 0 & 0.35 & 0.30 & 0.57 & 0.26 & 0.16 & 0.58 & \\
\hline & 39092 & $\begin{array}{l}\text { Dollis Brook at } \\
\text { Hendon Lane } \\
\text { Bridge }\end{array}$ & 23.7 & 692 & 0 & 0.26 & 0.22 & 0.46 & 0.18 & 0.10 & 0.72 & \\
\hline & 39131 & $\begin{array}{l}\text { Brent at Costons } \\
\text { Lane Greenford }\end{array}$ & 146.2 & 679 & 0 & 0.44 & 0.37 & 0.66 & 0.28 & 0.18 & 0.54 & \\
\hline & 39137 & $\begin{array}{l}\text { Yeading West at } \\
\text { Gutteridge Wood }\end{array}$ & 17.9 & 669 & 0 & 0.41 & 0.35 & 0.70 & 0.29 & 0.33 & 0.38 & \\
\hline \multirow[t]{4}{*}{$\begin{array}{l}\text { Manchester } \\
\text { /Liverpool }\end{array}$} & 68020 & $\begin{array}{l}\text { Gowy at Bridge } \\
\text { Trafford }\end{array}$ & 148.7 & 730 & 0 & 0.02 & 0.04 & 0.08 & & & & \\
\hline & 69013 & $\begin{array}{l}\text { Sinderland Brook at } \\
\text { Partington }\end{array}$ & 44.7 & 801 & 66 & 0.35 & 0.30 & 0.53 & 0.10 & 0.19 & 0.71 & \\
\hline & 69030 & $\begin{array}{l}\text { Sankey Brook at } \\
\text { Causey Bridges }\end{array}$ & 147.7 & 922 & 74 & 0.19 & 0.19 & 0.30 & 0.18 & 0.0 & 0.82 & 0.18 \\
\hline & 69032 & Alt at Kirkby & 96.6 & 885 & 73 & 0.33 & 0.29 & 0.45 & 0.18 & 0.08 & 0.74 & 0.21 \\
\hline \multirow[t]{2}{*}{ Newcastle } & 23018 & $\begin{array}{l}\text { Ouseburn at } \\
\text { Woolsington }\end{array}$ & 11.4 & 695 & 0 & 0.07 & 0.07 & 0.12 & & & & \\
\hline & 23016 & $\begin{array}{l}\text { Ouseburn at Crag } \\
\text { Hall }\end{array}$ & 53.8 & 697 & 0 & 0.30 & 0.25 & 0.41 & 0.11 & 0.19 & 0.70 & 0.12 \\
\hline
\end{tabular}




\subsection{Precipitation and discharge data}

Daily precipitation data were available for a 25 -year period (1990 to 2014, inclusive) from a national $1 \mathrm{~km}$ gridded rainfall product (Lewis et al., 2018b). Catchment boundary data from the NRFA were extracted for the calculation of catchment areal averaged precipitation totals (National River Flow Archive, 2017). Daily discharge data (1990 to 2014) and associated catchment descriptors were also extracted from the NRFA. Using the catchment area, the discharge at the outlet was converted to monthly runoff ( $\mathrm{mm}$ ) and divided by the areal averaged monthly precipitation to calculate the monthly runoff coefficients.

In addition to the daily precipitation and discharge data, 25 years of hourly rainfall-runoff records were obtained for nine of the urban catchments. These data were used in the verification of the derived separate sewer fraction (Section 4.2).

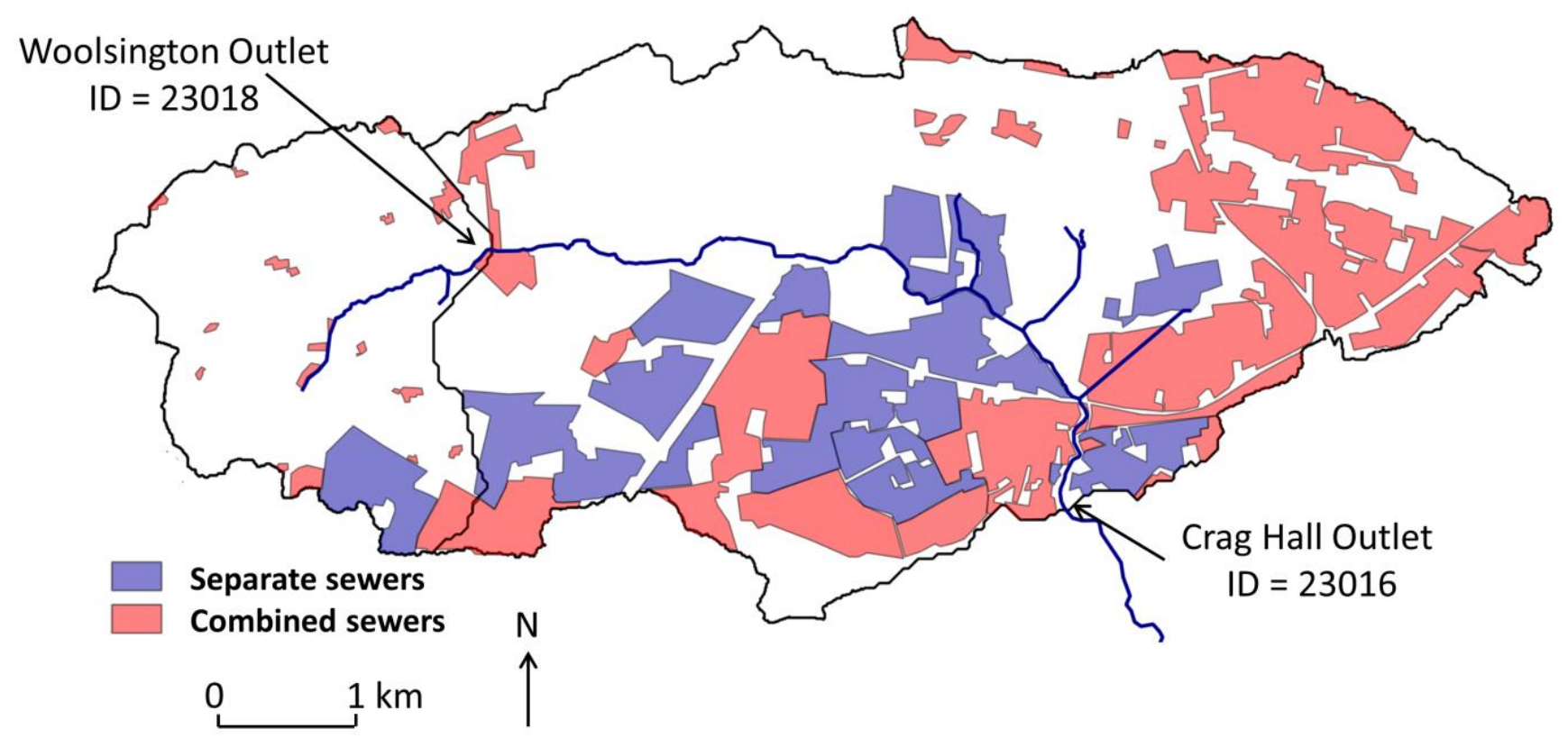

Fig. 3. The Ouseburn at Woolsington (23018) and the Ouseburn at Crag Hall (23016) case study catchments. The urban areas are highlighted either as blue (separate sewers) or red (combined sewers) 


\subsection{Total impervious fraction}

In this work three alternate estimates of the TIA were derived from spatially distributed data sources (Table 2). These estimates were used in the assessment of the impervious fraction $\left(F_{s}+F_{c}\right)$ calculated in this work using the monthly runoff coefficients. Two of the three estimates were derived from the OS MasterMap Topography Layer and the other estimate uses the UK Land Cover Map 2007 (LCM 2007) remotely sensed data set (Morton et al. 2014). The OS MasterMap Layer is a vector dataset of the ground mapping of individual features that are hierarchically assigned to descriptive groups including roads, buildings, and gardens and then to make classes. The make classes include "manmade", constructed features such as areas of concrete and paved-areas, "natural", nonmanmade features such as vegetation, and "multiple", a mixture of natural and manmade surfaces. Here, the features were classified as either pervious or impervious (Table A.1). However, the assignment of the feature type "General Surface; Multiple", is complicated as it includes gardens, which may have been paved for car parking, contributing runoff to adjacent roads and other impervious areas drained by sewers. It is expected that paved gardens and highly compacted urban soils will behave as an impervious part of the catchment (Warhurst et al, 2014), while wellestablished gardens will allow infiltration and so be a pervious part of the catchment. To provide a lower and an upper estimate of TIA, all gardens were firstly assigned as pervious (hereinafter termed OSMM) and then impervious (OSMM+).

Table 2. Total Impervious Area (TIA) data sources

\begin{tabular}{|c|c|c|c|}
\hline Name & Resolution & Data Source & Gardens \\
\hline LCM 2007 & $25 m$ & Satellite & $\begin{array}{c}\text { Insufficient resolution } \\
\text { to categorize }\end{array}$ \\
\hline OSMM & $\begin{array}{l}\text { Vector data converted to } \\
\qquad 1 \mathrm{~m} \text { raster }\end{array}$ & Ground mapping & $\begin{array}{l}\text { Included in pervious } \\
\text { fraction }\end{array}$ \\
\hline OSMM+ & $\begin{array}{l}\text { Vector data converted to } \\
\qquad 1 \mathrm{~m} \text { raster }\end{array}$ & Ground mapping & $\begin{array}{c}\text { Included in impervious } \\
\text { fraction }\end{array}$ \\
\hline
\end{tabular}

LCM 2007 is derived from the classification of satellite images and digital cartography and is widely used in hydrological and ecological studies (e.g. Miller and Hess, 2017). It has a $25 \mathrm{~m}$ grid resolution, hence the detailed patchwork of built-up and green areas found in urban catchments is poorly represented. There are 23 different classes, including an urban and a suburban assignment. Miller 
and Grebby (2014) suggest calculating TIA as equal to the urban fraction plus half the suburban fraction. This fraction provides the third estimate of TIA used in this work.

The TIA values derived from the LCM 2007, OSMM and OSMM+ data for the 25 catchments are provided in Table 1. For the urban catchments, the TIA values derived from the LCM 2007 data set fall between the two values derived from the OS MasterMap layer but are closer to those with the assignment of gardens as pervious areas (OSMM). For the rural catchments, the LCM 2007 values are smaller than those derived from both methods using the OS MasterMap layer. This appears to be because small isolated features, such as farm buildings, are not included in the LCM 2007 impervious area due to the coarse pixel size $(25 \mathrm{~m})$ relative to the size of the features. An example of the assignment of land-use types is provided in Appendix A1 for a suburban area within the Ouseburn case study catchment at Crag Hall.

\subsection{Event based rainfall-runoff}

In this work a new method is developed using monthly runoff coefficients to give an estimate of the separate sewer, $\left(F_{s}\right)$, combined sewer $\left(F_{c}\right)$ and pervious $\left(F_{p}\right)$ fractions. If hourly or sub-hourly rainfall and discharge data are available then the standard method of calculating the EIA (which corresponds to $F_{s}$ in this work) in catchments less than $20 \mathrm{~km}^{2}$ is through the analysis of the event based rainfallrunoff response (Boyd, et al., 1993; Jones et al., 2003; Ebrahimian et al., 2016b; Epps and Hathaway, 2018). The new approach has two advantages over this standard event-based rainfall-runoff approach. Firstly, it uses more readily available data sets. For example, it is much easier to obtain daily or monthly river discharge data than hourly/sub hourly discharge data. In the UK, the National River Flow Archive (2017) has daily discharge records for over 1,500 gauging stations and the GRDC (2019) has daily and monthly discharge data for more than 9,900 stations from 159 countries. Secondly, the fraction $F_{c}$, where generated runoff in combined sewers is removed from and treated outside the catchment, cannot be estimated using the event-based rainfall-runoff response, as there is no flow past the catchment outlet. However, the event-based rainfall-runoff response is a useful method to verify the results produced using the new method.

Twenty-five years of hourly rainfall and runoff data were obtained for nine of the urban catchments including the Ouseburn at Crag Hall case study catchment. For these nine catchments, events were extracted subject to there being no precipitation in the 12 hours prior to the event and none in the subsequent 48 hours (this simplifies baseflow separation). Once extracted, the baseflow was removed using the master recession curve method (Posavec et al. 2010). Following the approach of Ebrahimian et al (2016b), each event was classified as either an EIA sourced or combined event. The 
discharge in EIA sourced events is assumed to only come from impervious areas directly connected to the drainage system, whereas combined events also include flows from pervious surfaces. The classification was carried out using successive weighted least squared regression analysis of the observed runoff and rainfall events, removing combined events if the runoff exceeded the regression line by a given depth, the $\delta c$ EIA criterion. The slope of the final regression line (which for EIA sourced events is fraction of the rainfall that produces runoff) is considered to be the event based separate sewer fraction $\left(F_{s}\right)$ and the results are shown in Table 1.

\subsection{Monthly rainfall runoff coefficients}

The monthly rainfall-runoff coefficients were calculated for 20 urban and 5 rural catchments (Fig. 4, Table A.2), with the data from paired rural and urban catchments providing the basis for calculating the three fractions $\left(F_{s}, F_{c}\right.$ and $\left.F_{p}\right)$. In most catchments, the lowest monthly precipitation typically occurs in spring (March) and the highest in autumn (October). However, the highest monthly runoff coefficient values occur in winter (December-February) and the lowest values in summer (JuneAugust), reflecting seasonal patterns of evaporation.
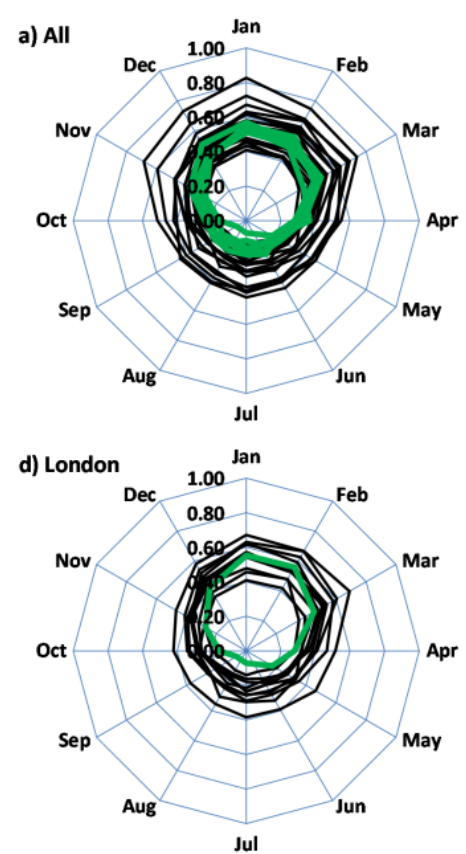
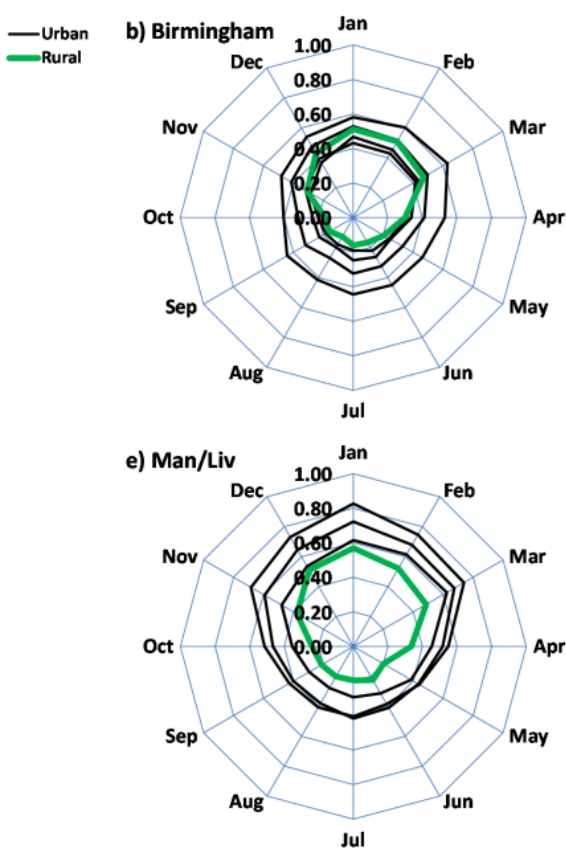
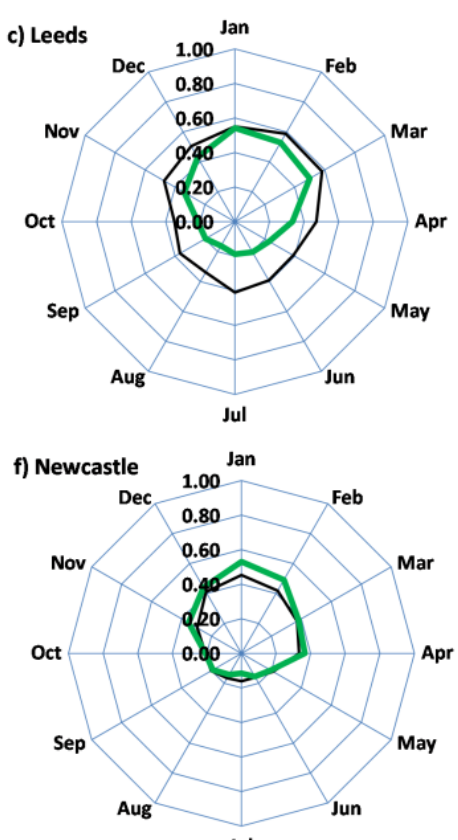

Jul

Fig 4. Monthly runoff coefficients for the five rural and 20 urban catchments

The important feature of the monthly runoff coefficient is that all the rural catchments have a similar response, whereas urban catchments show considerable variation between catchments. These differences are driven by the impervious fractions and the sewer network. Firstly, impervious areas increase the runoff coefficient in both summer and winter, but particularly in summer as the higher evaporation means there is a soil moisture deficit and consequently lower runoff in rural 
catchments. Secondly, combined sewers reduce the runoff coefficient in both summer and winter due to the export of runoff to wastewater treatment plants. It is this large variation between the runoff coefficients that enables the three fractions $\left(F_{s}, F_{c}\right.$ and $\left.F_{p}\right)$ to be calculated.

\subsection{Hydrological modelling}

The separate sewer, combined sewer and pervious fractions $\left(F_{s}, F_{c}\right.$ and $\left.F_{p}\right)$ calculated in this work were used in a hydrological modelling study of three of the urban catchments (Fig. 2). These are the Ouseburn at Crag Hall (23016, our main case study catchment), Salmon Brook at Edmonton (38014, with low urban fraction), and Yeading West at Gutteridge Wood (39137, high urban fraction). They were selected as they cover a range of urban fractions. The purpose of this modelling is to establish whether inclusion of the three fractions $\left(F_{s}, F_{c}\right.$ and $\left.F_{p}\right)$ can reconcile errors in stream flow mass balance.

The Shetran hydrological model (Ewen et al. 2000, Birkinshaw et al, 2010) was selected for use here as it is physically-based and spatially-distributed, allowing explicit representation of the impervious areas. The model is usually applied to predominantly rural catchments (Birkinshaw et al. 2014; Birkinshaw et al. 2017) but it can take into account the different hydrological response within impervious and pervious areas. It includes components for vegetation interception and transpiration, overland flow, variably saturated subsurface flow and channel-aquifer interactions. Solutions to the governing, physics-based, partial differential equations of mass and momentum are achieved on a three-dimensional grid using finite-difference equations (https://research.ncl.ac.uk/shetran/).

To account for the sealing of the ground surface in impervious areas, the saturated conductivity is set to zero, preventing infiltration. To account for evaporation where there are separate sewers, $20 \%$ of the precipitation is removed and no additional evaporation is considered (see Section 3.2 ). $100 \%$ of the precipitation is removed in areas where there are combined sewers. A high Strickler (low roughness) overland flow parameter of $10 \mathrm{~m}^{1 / 3} \mathrm{~s}^{-1}$ is specified for impervious areas to take into account the effect of separate sewers, with rapid flow of water to and within the pipe network. The value selected is based on typical values obtained during previous calibrations of urban areas (Op de Hipt et al., 2017; Sreedevi et al., 2019).

A grid resolution of 100m was used for the smaller Salmon Brook at Edmonton (38014) and Yeading West at Gutteridge Wood (39137) catchments, and 200m for the larger Ouseburn at Crag Hall (23016) catchment (Fig. A.2). While this is still relatively coarse in relation to the highly 
heterogeneous nature of the urban environment, it allows a more adequate spatial partitioning of the runoff than in lumped and semi-distributed hydrological models.

For the assessment of water balance, it is important to establish independence between the estimation of the sewer fractions and the modelling. Consequently, the modelling did not consider changes to the parameters controlling evaporation (Table A.4). The parameters were specified using an existing library of values that were developed for a UK national hydrological assessment (Lewis et al., 2018a). This library was also used to specify the soil properties (Table A.5).

For each catchment four different scenarios were simulated. Firstly, the existing urban area was classified as grassland, the predominant land cover in the catchment (scenario "NoUrb"). This provides a baseline simulation against which the impact of urbanisation can be assessed. Next, the urban areas were assumed sealed, drained by either all separate sewers (scenario "SS") or all combined sewers (scenario "CS"). Fourthly, the separate and combined sewer fractions calculated in this work were used (scenario "SandC").

For the Ouseburn at Crag Hall, the location of areas within the catchment containing separate and combined sewers are known, allowing the correct spatial distribution to be assigned in scenario "SandC". For the other two catchments the locations are unknown. For these catchments, each grid square within the urban fraction is assumed to have both separate and combined sewers with the fraction of each depending on the value calculated in this work. Gridded $1 \mathrm{~km}$ resolution hourly rainfall data (Lewis et al. 2018b) and daily potential evapotranspiration data were used (Robinson et al. 2016).

\section{Method to calculate the separate sewer $\left(F_{s}\right)$, combined sewer $\left(F_{c}\right)$ and pervious $\left(F_{p}\right)$ fractions}

\subsection{Development of the equations}

The purpose here is to estimate $F_{s}, F_{c}$ and $F_{p}$ for a study catchment using monthly rainfall-runoff records. This considers a conceptual model of an urban catchment (Fig. 5), which corresponds to the left part of Fig. 1.

The areal fractions calculated by the model correspond to the area fractions by which the water reaches the catchment outlet, rather than the area fraction on which the precipitation falls. Runoff generated in fraction $F_{s}$ reaches the catchment outlet via the sewer system/drainage network, while the contributions from $F_{p}$ reach the catchment outlet via soil infiltration and channel-aquifer 
interactions. Hence, an impervious area (e.g. a road) that drains to a previous area (a garden) is assigned to the $F_{p}$ fraction, and similarly an area draining to a separate sewer system that is connected to a Sustainable Drainage Systems (SuDS) pond is also part of the $F_{p}$ fraction. Areas of highly compressed soil are assigned as part of the $F_{s}$ fraction and leakage from combined sewers (e.g Minnig et al. 2018) is included as part of the $F_{p}$ fraction.

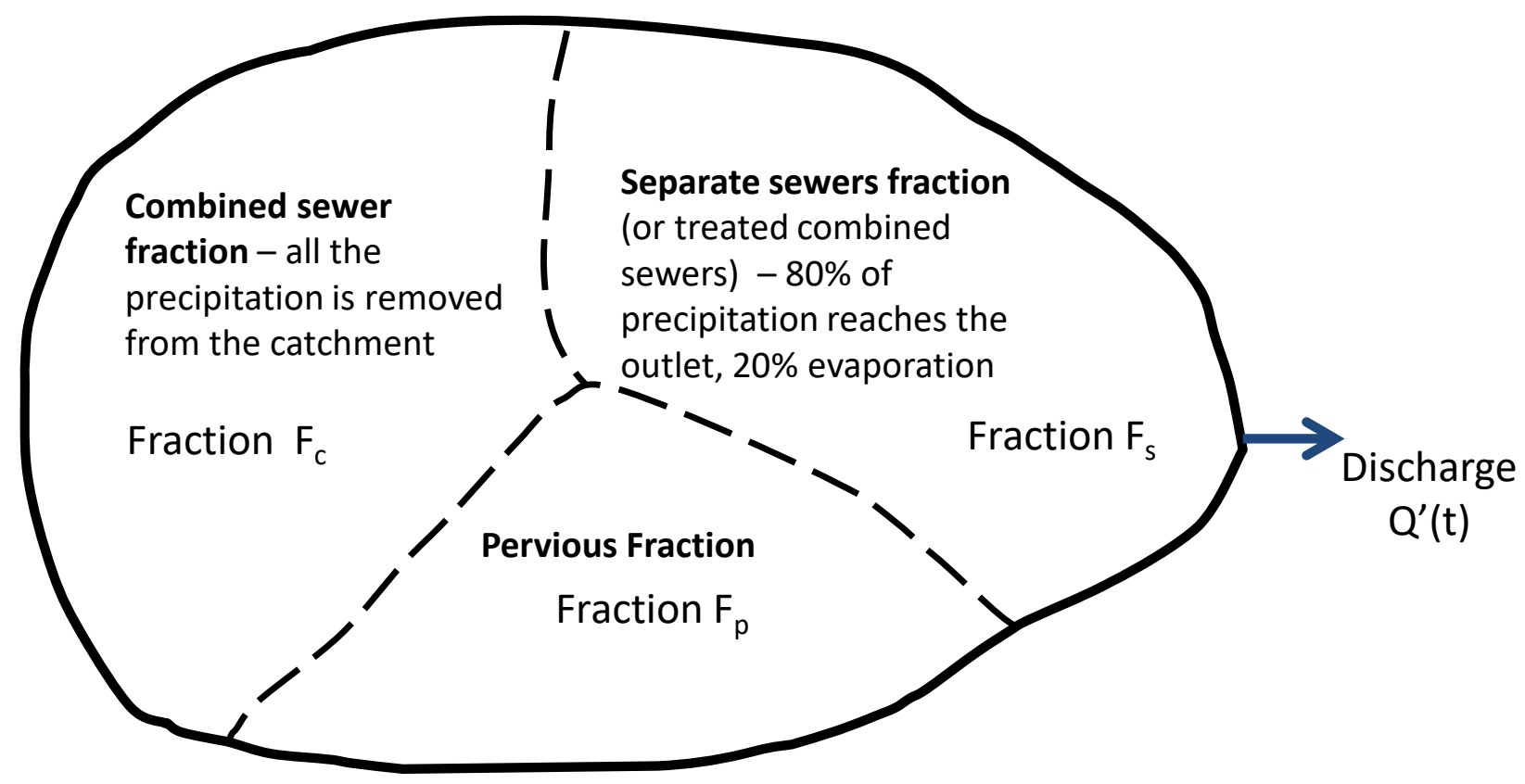

Fig. 5. Schematic representation of an urban catchment. The three fractions correspond to the pathways by which the water reaches the catchment outlet or is exported from the catchment.

The following equations are applied on a calendar month basis (i.e. $t=1, \ldots, 12) . Q(\mathrm{~mm})$ is the longterm discharge, $P(\mathrm{~mm})$ is long-term catchment areal average precipitation and $\mathrm{R}$ is the runoff coefficient (0-1). The subscripts $s, c$ and $p$ denote separate sewers, combined sewers and pervious areas, respectively.

The estimated long-term monthly average discharge $Q^{\prime}$ at the catchment outfall comprises contributions from the three types depicted in Fig. 5:

$$
Q^{\prime}(t)=Q^{\prime}{ }_{s}(t)+Q^{\prime}{ }_{c}(t)+Q^{\prime}{ }_{p}(t)
$$

The runoff from each area depends on the runoff coefficient of that area, the fraction of the catchment of that type and the precipitation: 


$$
\begin{aligned}
& Q_{s}^{\prime}(t)=R_{s} * F_{s} * P(t) \\
& Q_{c}^{\prime}(t)=R_{c} * F_{c} * P(t) \\
& Q_{p}^{\prime}(t)=R_{p} * F_{p} * P(t)
\end{aligned}
$$

Hence from Eqns. 1 -4:

$$
Q^{\prime}(t)=R_{s} * F_{s} * P(t)+R_{c} * F_{c} * P(t)+R_{p} * F_{p} * P(t)
$$

Considering the separate sewer fraction $\left(F_{s}\right), 80 \%$ of precipitation enters the drainage system, with a $20 \%$ loss to evaporation $\left(R_{s}=0.8\right)$, see Section 3.2 for a discussion of this issue. Runoff entering the combined sewer network $\left(F_{c}\right)$ is exported from the catchment and does not contribute to river discharge $\left(R_{c}=0\right)$, except if the waste water treatment plant is located within the catchment, in which case it is assumed to be part of the separate sewer fraction. The runoff coefficient for the pervious area $R_{p}$ is time varying (on calendar month basis) due to the seasonal variations in evaporation and subsurface storage, and the value is obtained from the analysis of rainfall-runoff records in a paired rural catchment:

Hence from Eqn. 5:

$$
\mathrm{Q}^{\prime}(\mathrm{t})=0.8 * \mathrm{~F}_{\mathrm{s}} * \mathrm{P}(\mathrm{t})+\mathrm{R}_{\mathrm{p}}(\mathrm{t}) * \mathrm{~F}_{\mathrm{p}} * \mathrm{P}(\mathrm{t})
$$

The sum of the three area fractions is equal to 1, therefore:

$$
F_{c}=1-F_{s}-F_{p}
$$

There are 12 simultaneous equations (Eqn. 6) that provide the 12 monthly estimates of long-term average discharge $\left(Q^{\prime}\right)$, for which the 12 observed monthly long-term average discharges are available (Q). Hence, for each catchment there are two unknowns, $F_{s}$ and $F_{p}$, which are numerically estimated by minimising the residuals between long-term average estimated $Q^{\prime}(t)$ and observed $Q(t) . F_{c}$ is then obtained from Eqn. 7.

In some catchments an additional term is required in Eqn. 6 to account for effluent inputs from waste water treatment plant for household waste water sourced from outside the catchment, adding an additional term to the equation, where $\mathrm{E}(\mathrm{mm})$ is the monthly effluent input:

$$
Q^{\prime}(t)=0.8 * F_{s} * P(t)+R_{p}(t) * F_{p} * P(t)+E
$$


According to NRFA, nine of the 20 urban catchments have significant augmentation from effluent inputs. These effluent flows were estimated here by extracting the minimum recorded daily discharge from hydrographs (noting that none of these catchments are baseflow dominated).

An example of the calculation of $F_{s}, F_{c}$ and $F_{p}$ for the Ouseburn case study catchment can be seen in Appendix A3.

Once the calculation of the three fractions $\left(F_{s}, F_{c}\right.$ and $\left.F_{p}\right)$ has been completed, the values can be used to improve the hydrological modelling of the catchment, with the methodology shown in Fig. 1.

\subsection{Discussion of the method}

A discussion of several aspects of the model development is considered in more detail in this section.

Firstly, the rural catchments were selected on the basis that they had low TIA values. However, all the rural catchments do have impervious areas (e.g. Table 1 shows a range of $3 \%-7 \%$ of catchment area using OSMM). It was simply assumed that half the impervious fraction contributed to separate sewers and half to the combined sewers. (Sensitivity tests indicated that the estimates of the separate and combined sewer fractions were insensitive to this assumption.)

Secondly, it is assumed that depression storage, which is subsequently lost to evaporation, is relatively small in urban areas. The model assumes that this evaporation loss is $20 \%$ of the precipitation falling in areas with separate sewers and the remaining $80 \%$ contributes to flow at the catchment outlet. Losses to evaporation are difficult to quantify, with a wide range of values given in the literature (Mansell and Rollet, 2006; Redfern et al., 2016). For roofs, Ragab et al. (2003a) estimated evaporation losses of 13 to $56 \%$ of precipitation, depending on the orientation and the slope. For four car parks and roads located in the south of England, Ragab et al. (2003b) found that $21-24 \%$ of the annual precipitation evaporated and Ramier et al. (2011) found that annually $10 \%$ of the precipitation evaporated in the city of Nantes in north-west France. Contradictory seasonal patterns were found by Hollis and Ovenden (1988) and Ragab et al. (2003b). Hence, a constant loss of $20 \%$ of precipitation to evaporation is a reasonable central estimate. Sensitivity tests with losses in the separate sewer fraction of both $0 \%$ and $40 \%$ of precipitation are considered in Section 4.4 .

Thirdly, the soils in the pervious areas within the urban catchments were assumed to have the same runoff coefficients as those in the rural catchments. It has been demonstrated that building activity within the urban environment produces compacted soils with low permeability and reduced infiltration (Gregory et al., 2006; Chen et al., 2014, Fletcher et al., 2013). However, similar issues of 
compaction exist in the rural catchments. For example, stock grazing and traffic loading in agricultural areas can cause compaction, enhancing surface runoff (Alaoui et al., 2018). Conversely, well-established urban gardens/parks within an urban catchment can have high permeability and infiltration rates (Bartens et al., 2008; Woltemade, 2010; Redfern et al., 2016). This complex issue of accounting for soil heterogeneity is an outstanding issue for hydrology modelling in general. It is suggested that further work is carried out to assess the effect of this assumption.

Fourthly, it is assumed the sewer network boundaries do not cross the surface water catchment boundaries, which is not always the case. for example, there can be parts of the separate sewer network outside a surface catchment boundary which flow across the surface water divide to the catchment outlet, so producing higher flows than expected (Vrebos et al., 2014). Similarly, there can be a reduced flow at the catchment outlet if the separate sewer network drains into an adjacent catchment. This is an issue for other approaches, such as the calculation of the separate sewer fraction using the event-based rainfall-runoff response, which also uses the catchment runoff. In order to quantify these additional flows or losses, details of the sewer network topology are required.

\section{Results and Discussion}

\subsection{Verification of the $F_{s}$ and $F_{c}$ fractions with the TIA}

The separate $\left(\mathrm{F}_{\mathrm{s}}\right)$ and combined $\left(\mathrm{F}_{\mathrm{c}}\right)$ sewer values estimated using Eqn. 8 are provided for each urban catchment in Table 1. The sum of $F_{s}$ and $F_{c}$ is a measure of the impervious area, but is not equal the TIA as it only includes the area fraction that flows into the sewer network. (Note, the TIA values are generated independently of those derived from Eqn. 8). In Fig. 6a, for each urban catchment the calculated $F_{s}+F_{c}$ value is plotted against the TIA derived from the LCM 2007 data and the OS MasterMap data set, assuming gardens respond as either pervious areas or impervious areas (i.e. OSMM and OSMM+, respectively). The line of equality shows that, for most catchments, the calculated $F_{s}+F_{c}$ falls between these lower and upper estimates of TIA, as would be expected, i.e. between the limits in which all gardens are assumed as either permeable or impermeable. For example, in the Ouseburn at Crag Hall catchment (23016) the $F_{s}+F_{c}$ value is 0.30 and the lower and upper estimates of TIA are 0.25 and 0.41 . However, for the less urbanised catchments the calculated impervious fraction in five of the 20 catchments were slightly lower than the TIA value where all gardens were assumed pervious (OSMM). This indicates that there may be parts of the catchment classified as impervious that are not hydraulically connected to the drainage network. For example, farm buildings, tracks and small roads classified as impervious in the OSMM data set, but which 
drain to pervious areas. For the highly urbanised catchments the calculated impervious fraction approaches the corresponding TIA value that assumes all gardens as impervious (OSMM+). The maximum impervious fraction $\left(F_{s}+F_{c}\right)$ calculated is 0.62 (ID 39137) for a catchment in London with the OSMM value of 0.35 and an OSMM+ value of 0.7 . This suggests that most of the gardens in the catchment act as impervious areas and are hydraulically connecting to the drainage network. Google areal images and Google Street View shows that the vast majority of houses in this catchment have converted their front gardens into paved areas to allow for car parking, but most of the houses still have 'green' rear gardens. One possible explanation, as discussed previously, is that many of these gardens have highly compacted soils which are acting as impervious areas. Alternatively, roadside verges, urban parks and school fields classified as pervious in the OSMM dataset, are acting as impervious areas. In general, it seems that the hydraulic connectivity of the urban part of a catchment increases as the urban fraction increases.
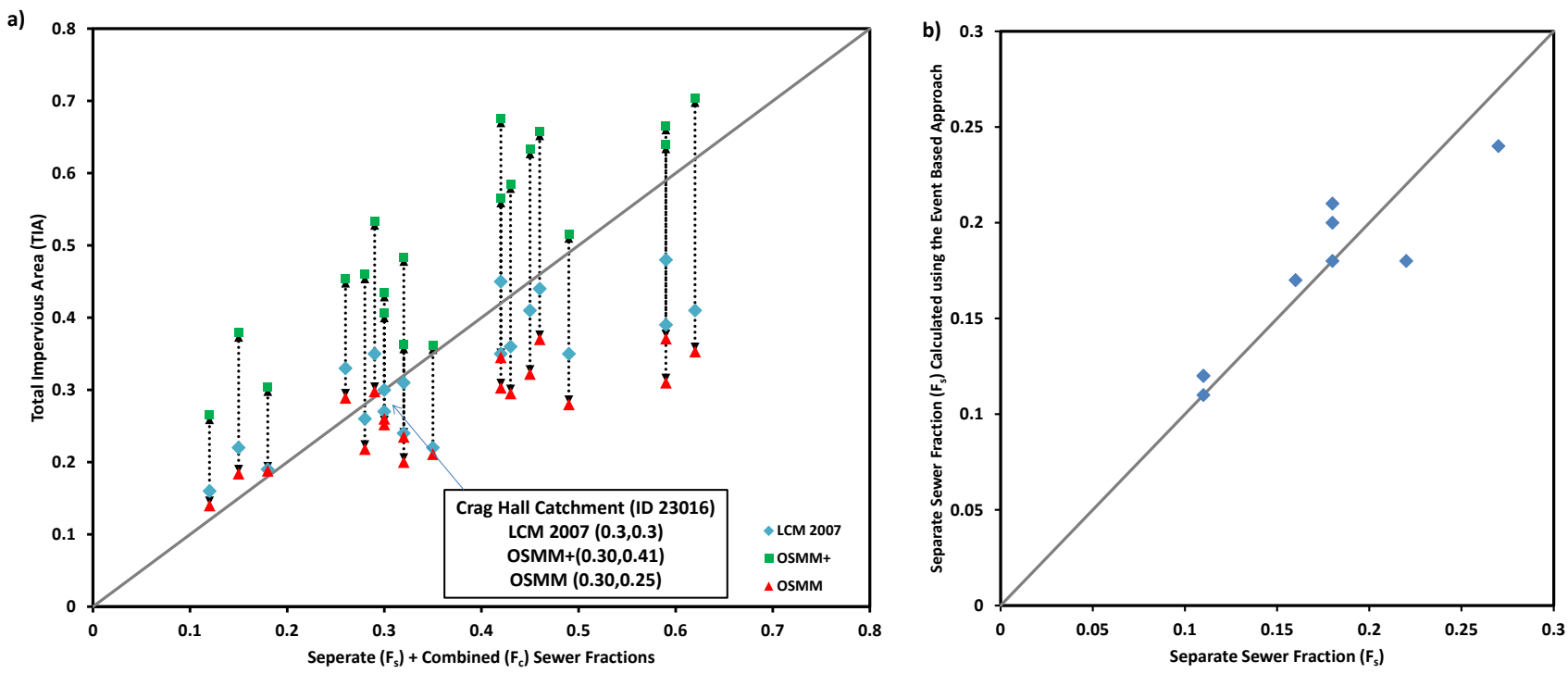

Fig. 6. a) Comparison between the calculated separate $\left(F_{s}\right)$ plus combined $\left(F_{c}\right)$ sewer fractions for the 20 urban catchments and the corresponding observed TIA calculated using three different methods (in OSMM the gardens are assigned to the pervious fraction and in OSMM+ the gardens are assigned to the impervious fraction). b) Comparison for nine catchments between the separate sewer fractions $\left(F_{s}\right)$ calculated in this work using monthly runoff coefficients and using the event-based approach (there are two values at $0.11,0.12$ ). The line of equality is shown in both $a$ ) and $b$ ). 


\subsection{Verification using the event-based rainfall runoff}

The separate sewer fraction $\left(F_{s}\right)$ for the 20 urban catchments are provided in Table 1 . The separate sewer fraction has been verified against the corresponding fraction calculated using the event-based rainfall runoff approach for nine catchments (see Section 2.4) where hourly observed discharge data were available. For the Ouseburn at Crag Hall case study catchment the separate sewer fraction $\left(F_{s}\right)$ calculated using the event based rainfall-runoff method is 0.12 , which is very similar to the value of $F_{s}$ of 0.11 calculated in this work using the monthly runoff coefficients. Similarly, the other eight catchments all show excellent correspondence (Fig. 6b). The largest difference is for Eastwood Brook at Eastwood catchment $(I D=37033)$ where $F_{s}$ calculated using the event-based rainfall-runoff approach is 0.22 and the $F_{s}$ calculated in this work is 0.18 . There is some evidence of the sewer network crossing the surface water catchment boundary in this catchment (see Section 3.2 ) and this could account for the difference. Overall, it is encouraging that the derived values agree so well, despite being calculated using different methodologies.

\subsection{Verification using the sewer network}

For the majority of the study catchments, there are no accurate details about the presence of separate or combined sewers. However, details of the sewer network for the Ouseburn at Crag Hall case study catchment (23016) have been published (Newcastle City Council, 2015) and are shown in Fig. 3, allowing verification of the separate sewer fraction to be carried out.

Table 1 shows the calculated percentage of the impervious area that is drained by separate sewers is $37 \%\left(F_{s}\right.$ is 0.11 and $F_{c}$ is 0.19 , hence the fraction is $\left.0.11 / 0.30\right)$, while the corresponding figure measured using information from the Newcastle City Council report gives a slightly higher value of $39 \%$. However, in a few housing estates there are separate sewers which feed into combined sewers in the downstream network, which has not been accounted for in Fig. 3. Hence, the value of $39 \%$ provides an upper estimate of the separate sewer fraction.

\subsection{Sensitivity tests with different evaporation losses}

The previous results have all assumed that depression storage, which is subsequently lost to evaporation, is $20 \%$ of the annual precipitation. Sensitivity tests were carried out with evaporation losses in the separate sewer fraction of both $0 \%$ and $40 \%$ of precipitation. The result of these changes had a minor impact on the impervious fraction $\left(F_{s}+F_{c}\right)$ value, but it did change the proportions of the separate sewer fraction $\left(F_{s}\right)$ and the combined sewer fractions $\left(F_{c}\right)$. Lower evaporation reduced the separate sewer fraction, $F_{s}$ (and hence increased the combined sewer 
fraction, $F_{c}$ ), with higher evaporation increasing the separate sewer fraction, $F_{s}$. (Note, for the pervious part of the catchment, evaporation is accounted through the use of the runoff coefficient from the paired rural catchment).

\subsection{Hydrological modelling}

The results of the hydrological modelling of three catchments under the four different scenarios are shown in Table 3. For the assessment of water balance, it is important to establish independence between the estimation of the sewer fractions and the modelling. Consequently, the modelling did not consider changes to the parameters controlling evaporation. Soil parameters were also not altered except the surface soil saturated hydraulic conductivity, which was calibrated to improve the quality of the hydrograph recessions (Table A.5). For example, for the Yeading West at Gutteridge Wood (39137) catchment the saturated conductivity was reduced to $6 \mathrm{~m} /$ day, which produced peakier flows and a steeper recession but did not affect the overall water balance.

Table 3. Hydrological modelling results. NSE is the Nash Sutcliffe Efficiency and PBias is the percentage bias in the outlet discharge. ${ }^{1}$ the results are for hourly discharge data. ${ }^{2}$ the results are for daily discharge data. Four scenarios are considered. "NoUrb" sets the entire urban area to grass with no sewers considered, "SS" the impervious area is simulated entirely with separate sewers, "CS" the impervious area is simulated entirely with combined sewers. "SandC" uses separate and combined sewers calculated in this work.

\begin{tabular}{|c|c|c|c|c|c|c|c|c|c|c|c|c|}
\hline \multirow[t]{2}{*}{$\begin{array}{c}\text { Catchment } \\
\text { Name }\end{array}$} & \multirow[t]{2}{*}{$\begin{array}{l}\text { Area } \\
\left(\mathrm{km}^{2}\right)\end{array}$} & \multirow{2}{*}{$\begin{array}{c}\text { Separate } \\
\text { sewer } \\
\text { fraction, } \\
F_{s}\end{array}$} & \multirow{2}{*}{$\begin{array}{c}\text { Combined } \\
\text { sewer } \\
\text { fraction, } \\
F_{c}\end{array}$} & \multirow{2}{*}{$\begin{array}{c}\text { Pervious } \\
\text { fraction, } \\
F_{p}\end{array}$} & \multicolumn{2}{|c|}{ NoUrb } & \multicolumn{2}{|c|}{ SS } & \multicolumn{2}{|c|}{ CS } & \multicolumn{2}{|c|}{ SandC } \\
\hline & & & & & NSE & PBias & NSE & PBias & NSE & PBias & NSE & PBias \\
\hline $\begin{array}{l}\text { Ouseburn at } \\
\text { Crag Hall } \\
(23016)^{1}\end{array}$ & 53.8 & 0.11 & 0.19 & 0.70 & 0.60 & +11.6 & 0.08 & +84.1 & 0.45 & -52.5 & 0.89 & -1.0 \\
\hline $\begin{array}{l}\text { Salmon Brook } \\
\text { at Edmonton } \\
(38014)^{2}\end{array}$ & 22.8 & 0.14 & 0.01 & 0.85 & 0.55 & -37.9 & 0.82 & +2.0 & 0.55 & -51.2 & 0.82 & +0.1 \\
\hline $\begin{array}{l}\text { Yeading West at } \\
\text { Gutteridge } \\
\text { Wood }(39137)^{2}\end{array}$ & 17.9 & 0.29 & 0.33 & 0.38 & 0.11 & -27.4 & -0.12 & +84.6 & 0.04 & -67.1 & 0.77 & +1.1 \\
\hline
\end{tabular}


For the Ouseburn catchment in scenario "NoUrb", where all urban areas are classified as grassland, the simulated discharge is higher than the observed discharge (PBias $=+11.6 \%$ ) and the Nash Sutcliffe Efficiency (NSE) is 0.6. For scenario "SS", where all sewers are considered as separate, the PBias is $84.1 \%$, demonstrating the overestimation in runoff due to sealed surfaces. In scenario "CS", where sewers are considered combined, there is a significant underestimation in discharge due to the export of runoff (PBias=-52.5\%). For scenario "SandC", using the fractions of separate and combined sewers calculated in this work the PBias is $-1.0 \%$ and the NSE is 0.89 . Fig. 7a shows a comparison of the hydrographs for scenarios "NoUrb" and "SandC" for the calendar year 2008. Runoff is significantly underestimated in scenario "NoUrb" under dry antecedent conditions (e.g. June 2008). The introduction of sealed surface and sewers in scenario "SandC" remedies this shortcoming. Under wetter winter conditions (Sept -Dec 2008), the recessions are too gradual and the base flow is too high in scenario "NoUrb", whereas these features are adequately simulated in scenario "SandC". In Fig. 7b, a 30-day section over August is shown for all four scenarios. Each event shows that in Scenario "SS" separate sewers significantly increase the discharge and in Scenario "CS" combined sewers significantly reduce the discharge.

a)

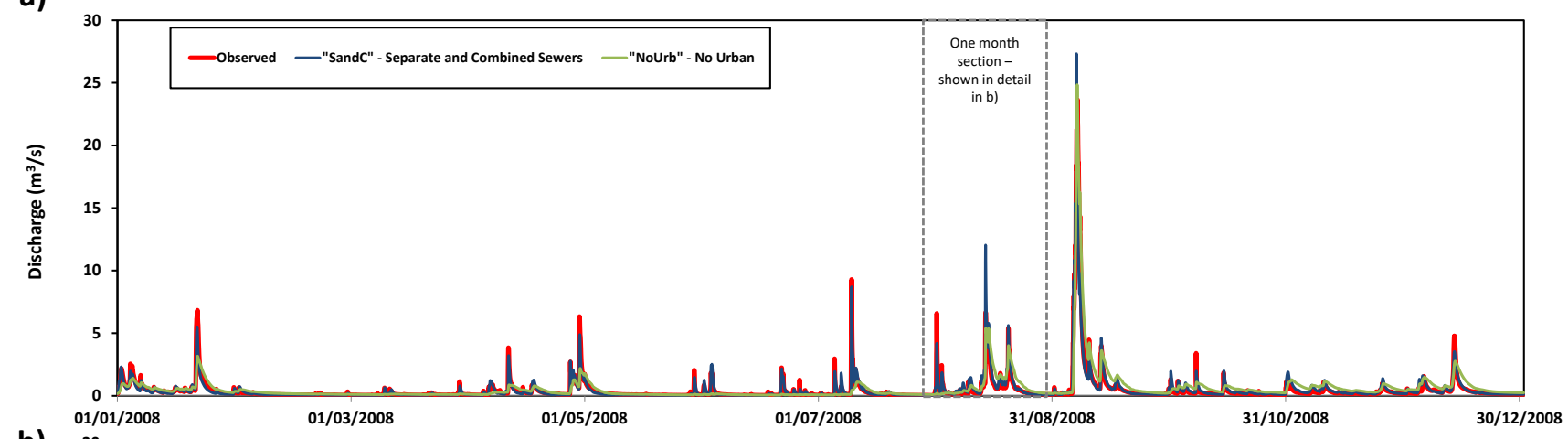

b)

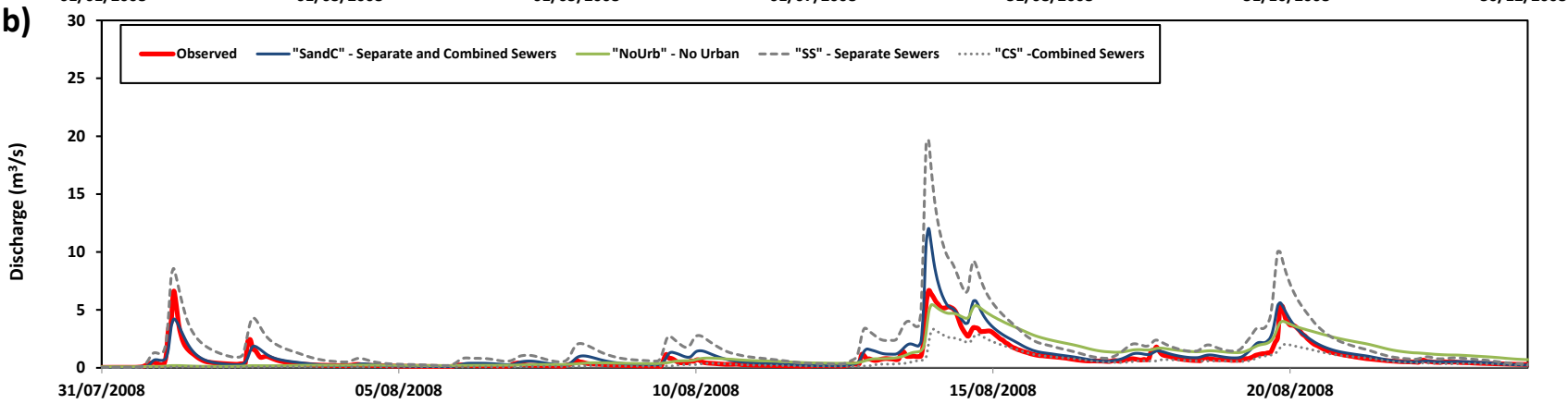

Fig. 7. Hydrological Modelling Simulation Results for the OuseBurn Crag Hall Catchment (ID 23016).

a) all of 2008 b) a section from $31 / 7 / 2008$ to $30 / 8 / 2008$. The simulation was carried out from $1 / 1 / 1990$ to $31 / 12 / 2014$. 
Considering all three catchments shown in Table 3, the highest NSE and the lowest PBias values are all attained when the sewer fractions calculated in this work are applied. However, it is noted that the NSE values for Salmon Brook (ID 38014) are very similar under scenarios "SS" and "SandC", which is due to the separate sewer fraction $\left(F_{s}\right)$ accounting for $95 \%$ of impervious area $\left(F_{s}+F_{c}\right)$. For the Yeading West catchment (ID 39137), the NSE under scenario "SandC" was 0.77, which is significantly higher than the values attained for the other scenarios. This is the most urbanised of the three catchments considered $\left(F_{s}+F_{c}=0.62\right)$, with the separate sewer fraction accounting for $46 \%$ of the impervious area $\left(F_{s}+F_{c}\right)$, hence the extreme assumptions under scenarios "SS" and "CS" are poor.

In hydrological modelling, the error between the observed and simulated outlet discharges are generally corrected during calibration through parameter compensation (Salvadore et al. 2015). In particular, the calibration of the parameters that affect the actual evaporation is often performed to correct for errors in the overall water balance (Guerreiro et al. 2017). Although this can produce good correspondence between the measure and simulated discharge, it is not satisfactory; as Beven (2019) states "getting good results for the wrong reasons can be misleading when we want to simulate the impacts of change". The hydrological modelling has demonstrated the importance of incorporating the correct fractions of separate and combined sewers, to avoid the need to calibrate the water balance. Hence, the model is getting the "right answers for the right reasons " (Kirchner, 2006).

Future work is planned on conducting hydrological modelling of the remaining catchments and assessing the effect of different spatial resolutions and the spatial locations of the separate and combined sewer fractions.

\section{Conclusions}

Hydrological models of urban and peri-urban catchments are often used by flood risk managers and planners in to help inform decision making. However, the models are generally limited by a lack of knowledge of the urban runoff processes within the catchments. In this work a novel method to calculate the separate sewer fraction, combined sewer fraction and a pervious fraction has been developed and applied to 20 urban river catchments. The method makes use of monthly runoff coefficients from an urban and a paired rural catchment and the algorithm is simple to implement. As the data requirements for this method are only the more readily available long term monthly rainfall-runoff records, it is particularly useful in catchments which do not have freely available 
sewer topology data or fine resolution hydrological time-series data, which makes alternative methods impossible to apply. To verify the method, the derived fractions were compared against map data and the standard method, which utilises hourly data. The results showed excellent correspondence.

Hydrological modelling was carried out for three catchments, partitioning the sewer network into a separate sewer fraction, which flows into the drainage network, and a combined fraction, which is removed from the catchment. The model was parameterised using an existing library of parameter values. Good agreement between the observed and simulated outlet hydrographs was achieved, and the volume of simulated flows were in very close correspondence to the observed. Scenarios simulated by converting the urban areas to grassland and partitioning the sewer network into either all separate or all combined sewers all gave less good simulations and, in most cases, very poor simulations and large errors in the hydrological mass balance. It is therefore recommended that prior to the application of detailed hydrological models for urban areas, the simple approach developed in this study is applied.

Two recent modifications to existing urban environments have the potential to cause considerable changes to the pervious and impervious fractions. Replacing pervious gardens with parking spaces (Warhurst et al., 2014; Kelly, 2018) will significantly increase the impervious fraction. On the other hand, the increased use of SuDS and green infrastructure (O'Donnell et al., 2020) will increase the infiltration and hence reduce the impervious fraction. The method developed in this work, in conjunction with hydrological modelling, provides a powerful means for initial quantification of the impacts of such changes on urban runoff and flooding.

Overall, we believe that this work provides an insight into the hydrological response of typical urban catchments where detailed sewer and hydrological data is not available. It takes into account both land use and sewerage factors, thereby providing a solid basis to further analyse and model improved design and management of flood and quality issues.

\section{Acknowledgements}

This work was carried out as part of the EPSRC funded Urban Flood Resilience project (EP/P004334/1). Paul Quinn and Russell Adams are thanked for their discussions about the hydrology and water quality issues in the Ouseburn case study catchments. Three anonymous 
reviewers are also thanked for their insightful comments that have resulted in a much improved and comprehensive paper.

\section{References}

Alaoui, A., Rogger, M., Peth, S., \& Blöschl, G. (2018). Does soil compaction increase floods? A review. Journal of hydrology, 557, 631-642.

Alberti, M., Booth, D., Hill, K., Coburn, B., Avolio, C., Coe, S., \& Spirandelli, D. (2007). The impact of urban patterns on aquatic ecosystems: An empirical analysis in Puget lowland sub-basins. Landscape and urban planning, 80(4), 345-361.

Arnold Jr, C. L., \& Gibbons, C. J. (1996). Impervious surface coverage: the emergence of a key environmental indicator. Journal of the American planning Association, 62(2), 243-258.

Bartens, J., Day, S. D., Harris, J. R., Dove, J. E., \& Wynn, T. M. (2008). Can urban tree roots improve infiltration through compacted subsoils for stormwater management?. Journal of Environmental Quality, 37(6), 2048-2057.

Beven, K. (2019). How to make advances in hydrological modelling. Hydrology Research, 50(6), 14811494.

Birkinshaw, S. J., Bathurst, J. C., \& Robinson, M. (2014). 45 years of non-stationary hydrology over a forest plantation growth cycle, Coalburn catchment, Northern England. Journal of Hydrology, 519, 559-573.

Birkinshaw, S. J., Guerreiro, S. B., Nicholson, A., Liang, Q., Quinn, P., Zhang, L., ... \& Fowler, H. J. (2017). Climate change impacts on Yangtze River discharge at the Three Gorges Dam. Hydrology and Earth System Sciences, 21(4), 1911.

Birkinshaw, S. J., James, P., \& Ewen, J. (2010). Graphical user interface for rapid set-up of SHETRAN physically-based river catchment model. Environmental Modelling \& Software, 25(4), 609-610. 
Bisht, D. S., Chatterjee, C., Kalakoti, S., Upadhyay, P., Sahoo, M., \& Panda, A. (2016). Modeling urban floods and drainage using SWMM and MIKE URBAN: a case study. Natural Hazards, 84(2), 749-776.

Booth, D. B., \& Jackson, C. R. (1997). Urbanization of aquatic systems: Degradation thresholds, stormwater detection, and the limits of mitigation 1. JAWRA Journal of the American Water Resources Association, 33(5), 1077-1090.

Boyd, M. J., Bufill, M. C., \& Knee, R. M. (1993). Pervious and impervious runoff in urban catchments. Hydrological Sciences Journal, 38(6), 463-478.

Burns, M. J., Walsh, C. J., Fletcher, T. D., Ladson, A. R., \& Hatt, B. E. (2015). A landscape measure of urban stormwater runoff effects is a better predictor of stream condition than a suite of hydrologic factors. Ecohydrology, 8(1), 160-171.

Chen, Y., Day, S. D., Wick, A. F., \& McGuire, K. J. (2014). Influence of urban land development and subsequent soil rehabilitation on soil aggregates, carbon, and hydraulic conductivity. Science of the Total Environment, 494, 329-336.

Coutu, S., Del Giudice, D., Rossi, L., \& Barry, D. A. (2012). Parsimonious hydrological modeling of urban sewer and river catchments. Journal of Hydrology, 464, 477-484.

Cuo, L., Lettenmaier, D. P., Mattheussen, B. V., Storck, P., \& Wiley, M. (2008). Hydrologic prediction for urban watersheds with the Distributed Hydrology-Soil-Vegetation Model. Hydrological Processes, 22(21), 4205-4213.

de Mello, K., Valente, R. A., Randhir, T. O., dos Santos, A. C. A., \& Vettorazzi, C. A. (2018). Effects of land use and land cover on water quality of low-order streams in Southeastern Brazil: Watershed versus riparian zone. Catena, 167, 130-138.

Ebrahimian, A., Gulliver, J. S., \& Wilson, B. N. (2016a). Effective impervious area for runoff in urban watersheds. Hydrological processes, 30(20), 371.

Ebrahimian, A., Wilson, B. N., \& Gulliver, J. S. (2016b). Improved methods to estimate the effective impervious area in urban catchments using rainfall-runoff data. Journal of hydrology, 536, 109-118. 
Ellis, J. B. (2013). Sustainable surface water management and green infrastructure in UK urban catchment planning. Journal of Environmental Planning and Management, 56(1), 24-41.

Epps, T. H., \& Hathaway, J. M. (2018). Establishing a Framework for the Spatial Identification of Effective Impervious Areas in Gauged Basins: Review and Case Study. Journal of Sustainable Water in the Built Environment, 4(2), 05018001.

Ewen, J., Parkin, G., \& O'Connell, P. E. (2000). SHETRAN: distributed river basin flow and transport modeling system. Journal of hydrologic engineering, 5(3), 250-258.

Fletcher, T. D., Andrieu, H., \& Hamel, P. (2013). Understanding, management and modelling of urban hydrology and its consequences for receiving waters: A state of the art. Advances in water resources, $51,261-279$.

Glenis, V., Kutija, V., \& Kilsby, C. G. (2018). A fully hydrodynamic urban flood modelling system representing buildings, green space and interventions. Environmental Modelling \& Software, $109,272-292$.

GRDC (2019) The Global Runoff Data Centre, 56068 Koblenz, Germany

Gregory, J. H., Dukes, M. D., Jones, P. H., \& Miller, G. L. (2006). Effect of urban soil compaction on infiltration rate. Journal of soil and water conservation, 61(3), 117-124.

Guerreiro, S. B., Birkinshaw, S., Kilsby, C., Fowler, H. J., \& Lewis, E. (2017). Dry getting drier-The future of transnational river basins in Iberia. Journal of Hydrology: Regional Studies, 12, 238-252.

Gustard, A., Bullock, A., \& Dixon, J. M. (1992). Low flow estimation in the United Kingdom. Institute of Hydrology.

Han, W. S., \& Burian, S. J. (2009). Determining effective impervious area for urban hydrologic modeling. Journal of Hydrologic Engineering, 14(2), 111-120. 
Hollis, G. E., \& Ovenden, J. C. (1988). The quantity of stormwater runoff from ten stretches of road, a car park and eight roofs in Hertfordshire, England during 1983. Hydrological processes, 2(3), 227243.

Hutchins, M. G., McGrane, S. J., Miller, J. D., Hagen-Zanker, A., Kjeldsen, T. R., Dadson, S. J., \& Rowland, C. S. (2017). Integrated modeling in urban hydrology: reviewing the role of monitoring technology in overcoming the issue of 'big data'requirements. Wiley Interdisciplinary Reviews: Water, 4(1), e1177.

Jacobson, C. R. (2011). Identification and quantification of the hydrological impacts of imperviousness in urban catchments: A review. Journal of environmental management, 92(6), 14381448.

Janke, B., Gulliver, J. S., \& Wilson, B. N. (2011). Development of techniques to quantify effective impervious cover. Project report no. 555, Centre for Transportation Studies, University of Minnesota.

Jones, T., Johnston, C., \& Kipkie, C. (2003). Using annual hydrographs to determine effective impervious area. In Stormwater and Urban Water Systems Modeling Conference. Practical Modeling of Urban Water Systems, Toronto, Ontario, Canada. Monograph (Vol. 11, pp. 291-306).

Kelly, D. A. (2018). Impact of paved front gardens on current and future urban flooding. Journal of Flood Risk Management, 11, S434-S443.

Kirchner, J. W. (2006). Getting the right answers for the right reasons: Linking measurements, analyses, and models to advance the science of hydrology. Water Resources Research, 42(3).

Lee, J. G., \& Heaney, J. P. (2003). Estimation of urban imperviousness and its impacts on storm water systems. Journal of Water Resources Planning and Management, 129(5), 419-426.

Lewis, E., Birkinshaw, S., Kilsby, C., \& Fowler, H. J. (2018a). Development of a system for automated setup of a physically-based, spatially-distributed hydrological model for catchments in Great Britain. Environmental modelling \& software, 108, 102-110. 
Lewis, E., Quinn, N., Blenkinsop, S., Fowler, H.J., Freer, J., Tanguy, M., Hitt, O., Coxon, G., Bates, P. and Woods, R. (2018b). A rule based quality control method for hourly rainfall data and a $1 \mathrm{~km}$ resolution gridded hourly rainfall dataset for Great Britain: CEH-GEAR1hr. Journal of Hydrology, 564, 930-943.

Mansell, M., \& Rollet, F. (2006). Water balance and the behaviour of different paving surfaces. Water and Environment Journal, 20(1), 7-10.

McGrane, S. J. (2016). Impacts of urbanisation on hydrological and water quality dynamics, and urban water management: a review. Hydrological Sciences Journal, 61(13), 2295-2311.

McMahon, G., Bales, J. D., Coles, J. F., Giddings, E. M., \& Zappia, H. (2003). Use of stage data to characterize hydrologic condition in an urbanizing environment. JAWRA Journal of the American Water Resources Association, 39(6), 1529-1546.

Miller, J. D., \& Grebby, S. (2014). Mapping long-term temporal change in imperviousness using topographic maps. International Journal of Applied Earth Observation and Geoinformation, 30, 9-20.

Miller, J. D., Kim, H., Kjeldsen, T. R., Packman, J., Grebby, S., \& Dearden, R. (2014). Assessing the impact of urbanization on storm runoff in a peri-urban catchment using historical change in impervious cover. Journal of Hydrology, 515, 59-70.

Miller, J. D., \& Hess, T. (2017). Urbanisation impacts on storm runoff along a rural-urban gradient. Journal of Hydrology, 552, 474-489.

Miller, J. D., \& Hutchins, M. (2017). The impacts of urbanisation and climate change on urban flooding and urban water quality: A review of the evidence concerning the United Kingdom. Journal of Hydrology: Regional Studies, 12, 345-362.

Minnig, M., Moeck, C., Radny, D., \& Schirmer, M. (2018). Impact of urbanization on groundwater recharge rates in Dübendorf, Switzerland. Journal of Hydrology, 563, 1135-1146. 
Morton, R.D., Rowland, C.S., Wood, C.M., Meek, L., Marston, C.G., Smith, G.M. (2014). Land Cover Map 2007 (25m raster, GB) v1.2. NERC Environmental Information Data Centre https://doi.org/10.5285/a1f88807-4826-44bc-994d-a902da5119c2

National River Flow Archive (2017). http://nrfa.ceh.ac.uk, Accessed date: 7 March 2017.

Newcastle city Council (2015). Ouseburn surface Water Management Plan.

https://www.newcastle.gov.uk/sites/default/files/Flooding/ouseburn_swmp_2015.pdf. Accessed date: 20 September 2017.

O'Donnell, E., Thorne, C., Ahilan, S., Arthur, S., Birkinshaw, S., Butler, D., ... \& Kapetas, L. (2020). The blue-green path to urban flood resilience. Blue-Green Systems, 2(1), 28-45.

O'Driscoll, M., Clinton, S., Jefferson, A., Manda, A., \& McMillan, S. (2010). Urbanization effects on watershed hydrology and in-stream processes in the southern United States. Water, 2(3), 605-648.

Op de Hipt, F., Diekkrüger, B., Steup, G., Yira, Y., Hoffmann, T., \& Rode, M. (2017). Applying SHETRAN in a tropical west African catchment (Dano, Burkina Faso)-Calibration, validation, uncertainty assessment. Water, 9(2), 101.

Oudin, L., Salavati, B., Furusho-Percot, C., Ribstein, P., \& Saadi, M. (2018). Hydrological impacts of urbanization at the catchment scale. Journal of Hydrology, 559, 774-786.

Palla, A., \& Gnecco, I. (2015). Hydrologic modeling of low impact development systems at the urban catchment scale. Journal of Hydrology, 528, 361-368.

Petrucci, G., \& Bonhomme, C. (2014). The dilemma of spatial representation for urban hydrology semi-distributed modelling: Trade-offs among complexity, calibration and geographical data. Journal of Hydrology, 517, 997-1007.

Posavec, K., Parlov, J., \& Nakić, Z. (2010). Fully automated objective-based method for master recession curve separation. Groundwater, 48(4), 598-603. 
Ragab, R., Bromley, J., Rosier, P., Cooper, J. D., \& Gash, J. H. C. (2003a). Experimental study of water fluxes in a residential area: 1. Rainfall, roof runoff and evaporation: the effect of slope and aspect. Hydrological Processes, 17(12), 2409-2422.

Ragab, R., Rosier, P., Dixon, A., Bromley, J., \& Cooper, J. D. (2003b). Experimental study of water fluxes in a residential area: 2. Road infiltration, runoff and evaporation. Hydrological Processes, 17(12), 2423-2437.

Ramier, D., Berthier, E., \& Andrieu, H. (2011). The hydrological behaviour of urban streets: long-term observations and modelling of runoff losses and rainfall-runoff transformation. Hydrological Processes, 25(14), 2161-2178.

Redfern, T. W., Macdonald, N., Kjeldsen, T. R., Miller, J. D., \& Reynard, N. (2016). Current understanding of hydrological processes on common urban surfaces. Progress in Physical Geography, 40(5), 699-713.

Robinson, E.L.; Blyth, E.; Clark, D.B.; Comyn-Platt, E.; Finch, J.; Rudd, A.C. (2016). Climate hydrology and ecology research support system potential evapotranspiration dataset for Great Britain (19612015) [CHESS-PE] . NERC Environmental Information Data Centre. https://doi.org/10.5285/8baf805d-39ce-4dac-b224-c926ada353b7

Roy, A. H., \& Shuster, W. D. (2009). Assessing Impervious Surface Connectivity and Applications for Watershed Management 1. JAWRA Journal of the American Water Resources Association, 45(1), 198209.

Salerno, F., Gaetano, V., \& Gianni, T. (2018). Urbanization and climate change impacts on surface water quality: Enhancing the resilience by reducing impervious surfaces. Water research, 144, 491502.

Salvadore, E., Bronders, J., \& Batelaan, O. (2015). Hydrological modelling of urbanized catchments: A review and future directions. Journal of Hydrology, 529, 62-81. 
Seo, Y., Choi, N. J., \& Schmidt, A. R. (2013). Contribution of directly connected and isolated impervious areas to urban drainage network hydrographs. Hydrology and Earth System Sciences, 17(9), 3473-3483.

Sisay, E., Halefom, A., Khare, D., Singh, L., \& Worku, T. (2017). Hydrological modelling of ungauged urban watershed using SWAT model. Modeling Earth Systems and Environment, 3(2), 693-702.

Shuster, W. D., Bonta, J., Thurston, H., Warnemuende, E., \& Smith, D. R. (2005). Impacts of impervious surface on watershed hydrology: a review. Urban Water Journal, 2(4), 263-275.

Slonecker, E. T., \& Tilley, J. S. (2004). An evaluation of the individual components and accuracies associated with the determination of impervious area. GIScience \& Remote Sensing, 41(2), 165-184.

Sreedevi, S., Eldho, T. I., Madhusoodhanan, C. G., \& Jayasankar, T. (2019). Multiobjective sensitivity analysis and model parameterization approach for coupled streamflow and groundwater table depth simulations using SHETRAN in a wet humid tropical catchment. Journal of Hydrology, 579, 124217.

United Nations (2019). World Population Prospects: The 2018 Revision, New York.

Vrebos, D., Vansteenkiste, T., Staes, J., Willems, P., \& Meire, P. (2014). Water displacement by sewer infrastructure in the Grote Nete catchment, Belgium, and its hydrological regime effects. Hydrology and Earth System Sciences, 18(3), 1119-1136.

Warhurst, J. R., Parks, K. E., McCulloch, L., \& Hudson, M. D. (2014). Front gardens to car parks: changes in garden permeability and effects on flood regulation. Science of the Total Environment, $485,329-339$.

Woltemade, C. J. (2010). Impact of residential soil disturbance on infiltration rate and stormwater runoff 1. JAWRA Journal of the American Water Resources Association, 46(4), 700-711.

Yang, G., Bowling, L. C., Cherkauer, K. A., \& Pijanowski, B. C. (2011). The impact of urban development on hydrologic regime from catchment to basin scales. Landscape and Urban Planning, 103(2), 237-247. 


\section{Appendix}

\section{A1. Details of Land Use Classification and the Total Impervious Area (TIA)}

An example of the assignment of land-use types is provided in Fig. A.1 for a suburban area within the Ouseburn case study catchment at Crag Hall. The Google Earth image in Fig. A.1a shows the patchwork of buildings, roads and gardens. In Fig. A.1b the gardens are assigned to the pervious fraction (OSMM) and in Fig. A.1c the gardens are included in the impervious fraction (OSMM+). To the south of the images in region 1 there are detached and semi-detached houses with large gardens that would ideally be included in the previous fraction. Alternatively, in region 2 there are terraced houses with paved gardens which should be included in the impervious fraction. However, the OS MasterMap layer assigns all residential gardens to the same make class (General Surface; Multiple see Table A.1) It would be expected that the actual TIA would fall somewhere between the lower and upper limits provided by OSMM and OSMM+. The LCM dataset, Fig. A.1d, classifies almost this entire area as either urban/suburban. Region 1, with large gardens, is assigned as suburban and region 2, with terraced houses, as urban.

Table A.1 Extracted land use data from the OSMM Topography Layer. * is the data type used in the OSMM Topography layer to specify gardens and it can be classed as either pervious or impervious

\begin{tabular}{lll}
\hline Descriptive Group & Make & Extracted land use data \\
\hline Building & All makes & Impervious \\
Roadside & Manmade & Impervious \\
& Multiple & Pervious \\
& Natural & Pervious \\
Road or Track & All makes & Impervious \\
General Surface & Manmade & Impervious \\
& Multiple* & Pervious/ Impervious \\
& Natural & Pervious \\
Natural Environment & All makes & Pervious \\
\hline
\end{tabular}




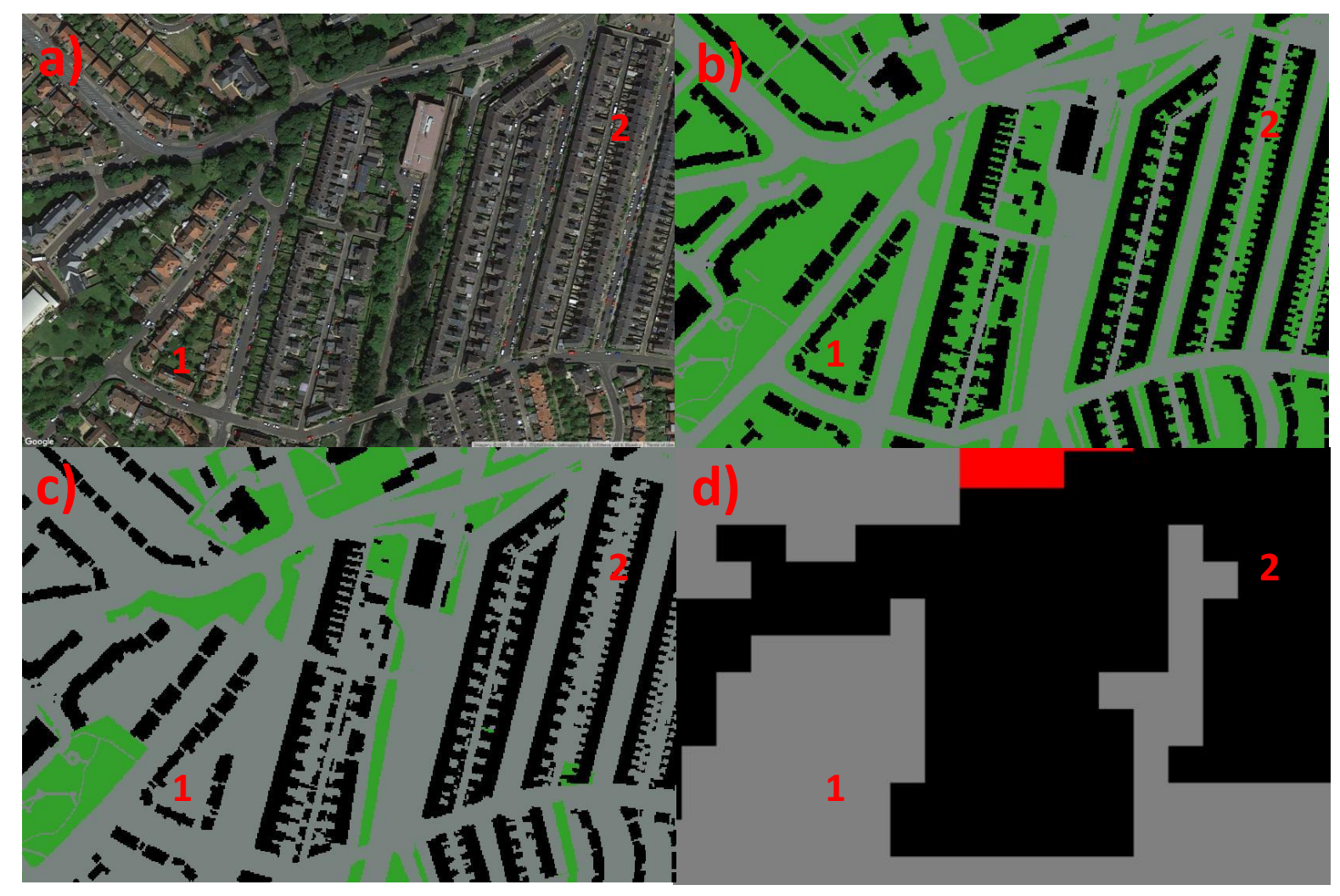

1 Region 1 - Big gardens 2 Region 2-Small gardens

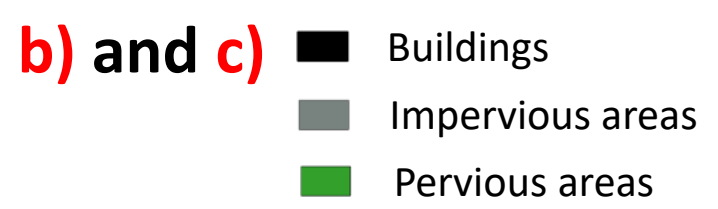

d) Urban

- Suburban

Broadleaved Woodland

Fig. A.1 Part of the Ouseburn at Crag Hall case study catchment. a) Google Earth image (@ Google, digital Globe), b) OS MM built-up area with gardens pervious (OSMM), c) OS MM built-up area with gardens impervious (OSMM+), d) LCM 2007 image 


\section{A2. Details of the monthly runoff coefficients for the five rural and 20 urban catchments}

Table A.2. Monthly runoff coefficients for the five rural and 20 urban UK catchments, separated out in relation to the nearest urban conurbation. Rural catchments in bold.

\begin{tabular}{|c|c|c|c|c|c|c|c|c|c|c|c|c|c|c|}
\hline \multirow{2}{*}{ Nearest city } & \multirow{2}{*}{$\begin{array}{l}\text { Catchment } \\
\text { number }\end{array}$} & \multirow{2}{*}{$\begin{array}{c}\text { Catchment } \\
\text { name }\end{array}$} & \multicolumn{12}{|c|}{ Month } \\
\hline & & & Jan & Feb & Mar & Apr & May & Jun & Jul & Aug & Sep & Oct & Nov & Dec \\
\hline \multirow[t]{11}{*}{ Birmingham } & 54096 & Hadley Brook & & & & & & & & & & & & \\
\hline & & at Wards & 0.51 & 0.51 & 0.47 & 0.30 & 0.21 & 0.17 & 0.16 & 0.13 & 0.16 & 0.16 & 0.31 & 0.43 \\
\hline & & Bridge & & & & & & & & & & & & \\
\hline & 28003 & $\begin{array}{l}\text { Tame at } \\
\text { Water Orton }\end{array}$ & 0.58 & 0.6 & 0.63 & 0.53 & 0.46 & 0.45 & 0.44 & 0.41 & 0.44 & 0.4 & 0.48 & 0.54 \\
\hline & 28039 & Rea at & & & & & & & & & & & & \\
\hline & & Calthorpe & 0.53 & 0.52 & 0.5 & 0.41 & 0.33 & 0.32 & 0.32 & 0.27 & 0.32 & 0.32 & 0.41 & 0.48 \\
\hline & & Park & & & & & & & & & & & & \\
\hline & 28066 & $\begin{array}{l}\text { Cole at } \\
\text { Coleshill }\end{array}$ & 0.43 & 0.43 & 0.42 & 0.34 & 0.25 & 0.26 & 0.25 & 0.2 & 0.23 & 0.23 & 0.32 & 0.39 \\
\hline & 54063 & Stour at & & & & & & & & & & & & \\
\hline & & Prestwood & 0.55 & 0.59 & 0.58 & 0.47 & 0.39 & 0.39 & 0.41 & 0.34 & 0.37 & 0.35 & 0.47 & 0.51 \\
\hline & & Hospital & & & & & & & & & & & & \\
\hline \multirow[t]{4}{*}{ Leeds } & 27064 & Went at & & & & & & & & & & & & \\
\hline & & Walden & 0.54 & 0.53 & 0.50 & 0.33 & 0.23 & 0.20 & 0.19 & 0.16 & 0.20 & 0.22 & 0.34 & 0.43 \\
\hline & & Stubbs & & & & & & & & & & & & \\
\hline & 27081 & $\begin{array}{l}\text { Oulton Beck } \\
\text { at Farrer Lane }\end{array}$ & 0.47 & 0.45 & 0.43 & 0.31 & 0.24 & 0.22 & 0.19 & 0.18 & 0.18 & 0.2 & 0.28 & 0.37 \\
\hline \multirow[t]{6}{*}{ London } & 37011 & $\begin{array}{l}\text { Chelmer at } \\
\text { Churchend }\end{array}$ & 0.55 & 0.56 & 0.45 & 0.28 & 0.17 & 0.09 & 0.07 & 0.06 & 0.06 & 0.15 & 0.27 & 0.42 \\
\hline & 37018 & Ingrebourne & & & & & & & & & & & & \\
\hline & & at Gaynes & 0.63 & 0.67 & 0.61 & 0.41 & 0.32 & 0.23 & 0.24 & 0.18 & 0.19 & 0.27 & 0.37 & 0.52 \\
\hline & & Park & & & & & & & & & & & & \\
\hline & 37019 & $\begin{array}{l}\text { Beam at } \\
\text { Bretons Farm }\end{array}$ & 0.55 & 0.56 & 0.48 & 0.35 & 0.27 & 0.23 & 0.23 & 0.19 & 0.2 & 0.26 & 0.32 & 0.44 \\
\hline & 37031 & $\begin{array}{l}\text { Crouch at } \\
\text { Wickford }\end{array}$ & 0.46 & 0.48 & 0.35 & 0.28 & 0.2 & 0.14 & 0.14 & 0.13 & 0.13 & 0.2 & 0.28 & 0.39 \\
\hline
\end{tabular}




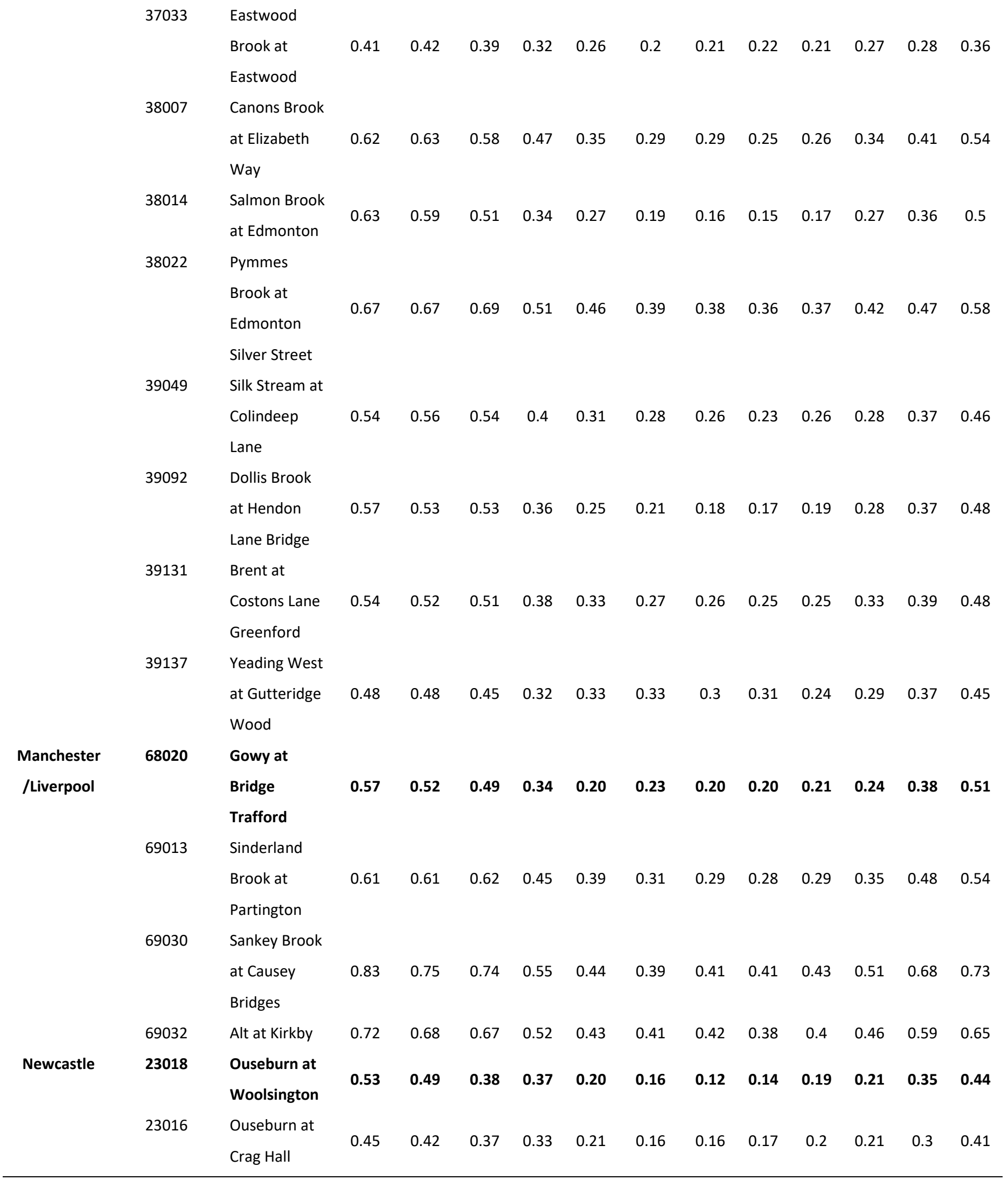




\section{A3. Worked example for the calculation of the separate sewer $\left(F_{s}\right)$, combined sewer $\left(F_{c}\right)$ and pervious $\left(F_{p}\right)$ fractions}

To illustrate the calculations of $\mathrm{F}_{\mathrm{s}}, \mathrm{F}_{\mathrm{c}}$ and $\mathrm{F}_{\mathrm{p}}$ consider the Ouseburn case study catchments (Section 2.1) where the fractions are calculated for the urban Crag Hall catchment (Table A.3). The estimated discharge $\left(Q^{\prime}\right)$ for each calendar month depends on the long-term monthly precipitation $(P)$, the runoff coefficient $\left(R_{p}\right)$ for the paired rural Ouseburn at Woolsington catchment (ID 23018), the effluent input $(E)$, and the separate sewer fraction $\left(F_{s}\right)$ and pervious fraction $\left(F_{p}\right)$ of total catchment area. For example, in January the monthly precipitation $(P)$ is $49.2 \mathrm{~mm}$, the runoff coefficient $\left(R_{p}\right)$ is 0.526 , the effluent input is 0 , and hence from Eqn. 8 the estimated discharge is:

$$
Q^{\prime}(m m)=0.8 * F_{s} * 49.2+0.526 * F_{p} * 49.2+0
$$

Therefore,

$$
Q^{\prime}(m m)=39.36 F_{s}+25.88 F_{p}
$$

and the observed long-term average monthly discharge $(Q)$ for January is $22.3 \mathrm{~mm}$. The two unknown values $\left(F_{s}\right.$ and $\left.F_{p}\right)$ are estimated by minimising the sum of the absolute residuals between the estimated discharge $\left(Q^{\prime}\right)$ and the observed discharge $(Q)$ for the twelve simultaneous equations (one for each month). This solution provides a value of $F_{s}$ of 0.109 and $F_{p}$ of 0.696 (hence from Eqn. 7 $F_{c}$ is 0.195). 
Table A.3 Calculation of the separate sewer fraction, $F_{s}(0.109)$, and the pervious fraction, $F_{p}(0.696)$, for the Ouseburn at Crag Hall catchment in Newcastle upon Tyne. An estimated discharge ( $\left.Q^{\prime}\right)$ is defined for each month (Eqn. 8). Then $F_{s}$ and $F_{p}$ are calculated by minimising the error between the estimated discharge $\left(Q^{\prime}\right)$ and the actual discharge $(Q)$ for the 12 simultaneous equations $\left(F_{c}=1-F_{s}\right.$ $\left.F_{p}\right)$.

\begin{tabular}{|c|c|c|c|c|c|c|}
\hline \multirow{5}{*}{ Month } & $P$ & $\mathrm{R}$ & $Q^{\prime}$ & $Q^{\prime}$ & $Q$ & Absolute \\
\hline & \multirow{4}{*}{$\begin{array}{l}\text { Precipitation } \\
(\mathrm{mm})\end{array}$} & Runoff & Estimated & Final & Actual & Error \\
\hline & & Coefficient from & Discharge $(\mathrm{mm})$, & Estimated & Discharge & $(\mathrm{mm})$ \\
\hline & & rural catchment & calculated from & Discharge & $(\mathrm{mm})$ & \\
\hline & & $23018(-)$ & Eqn 8 & $(\mathrm{~mm})$ & & \\
\hline Jan & 49.2 & 0.526 & $39.36 F_{s}+25.88 F_{p}$ & 22.3 & 22.3 & 0.0 \\
\hline Feb & 46.9 & 0.485 & $37.52 F_{s}+22.75 F_{p}$ & 19.9 & 19.6 & 0.3 \\
\hline Mar & 38.7 & 0.369 & $30.96 F_{s}+14.28 F_{p}$ & 13.3 & 14.4 & 1.1 \\
\hline Apr & 54.4 & 0.352 & $43.52 F_{s}+19.15 F_{p}$ & 18.1 & 18.2 & 0.1 \\
\hline May & 50.3 & 0.168 & $40.24 F_{s}+8.45 F_{p}$ & 10.2 & 10.7 & 0.5 \\
\hline Jun & 64.9 & 0.124 & $51.92 F_{s}+8.05 F_{p}$ & 11.3 & 10.5 & 0.8 \\
\hline Jul & 60.5 & 0.081 & $48.40 \mathrm{~F}_{\mathrm{s}}+4.90 \mathrm{~F}_{\mathrm{p}}$ & 8.7 & 9.7 & 1.0 \\
\hline Aug & 71.0 & 0.111 & $56.80 F_{s}+7.88 F_{p}$ & 11.6 & 11.7 & 0.1 \\
\hline Sep & 60.4 & 0.163 & $48.32 F_{s}+9.85 F_{p}$ & 12.1 & 12.3 & 0.2 \\
\hline Oct & 66.1 & 0.180 & $52.88 F_{s}+11.90 F_{p}$ & 14.1 & 13.7 & 0.4 \\
\hline Nov & 73.2 & 0.336 & $58.56 F_{s}+24.60 F_{p}$ & 23.5 & 21.6 & 1.9 \\
\hline Dec & 61.2 & 0.430 & $48.96 F_{s}+26.32 F_{p}$ & 23.6 & 25.1 & 1.5 \\
\hline
\end{tabular}


A4. Hydrological Modelling Details

a) Ouseburn at Crag Hall (23016)

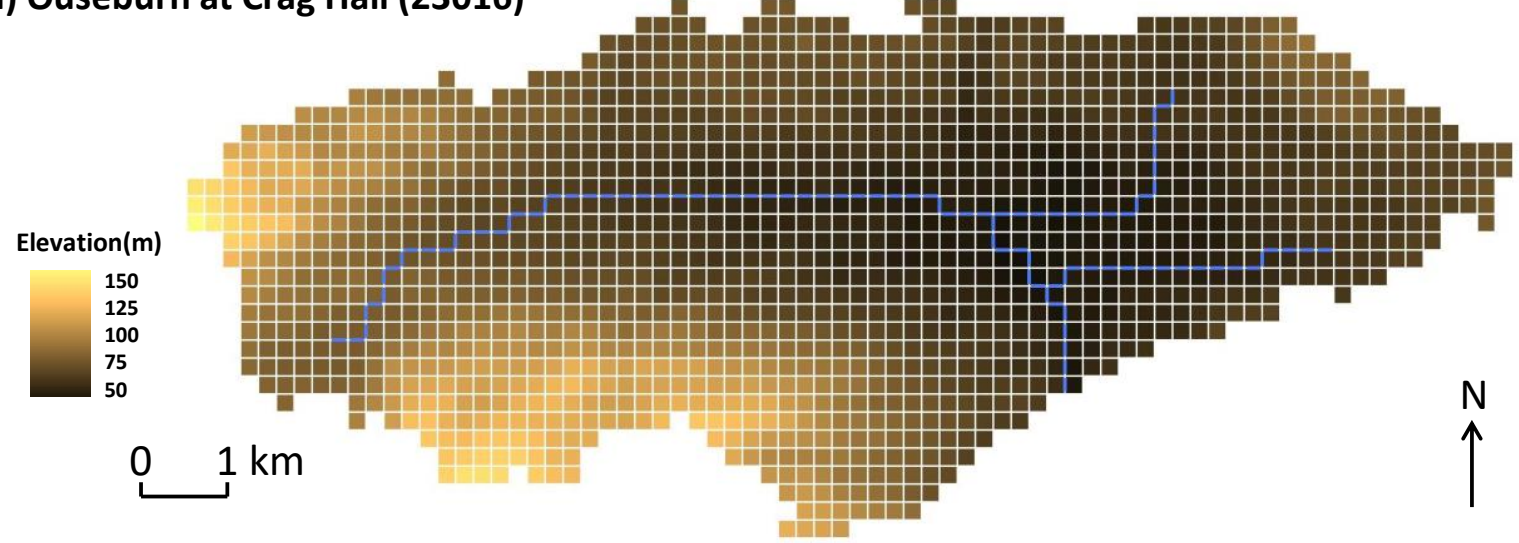

b) Yeading West at Gutteridge Wood (39137)
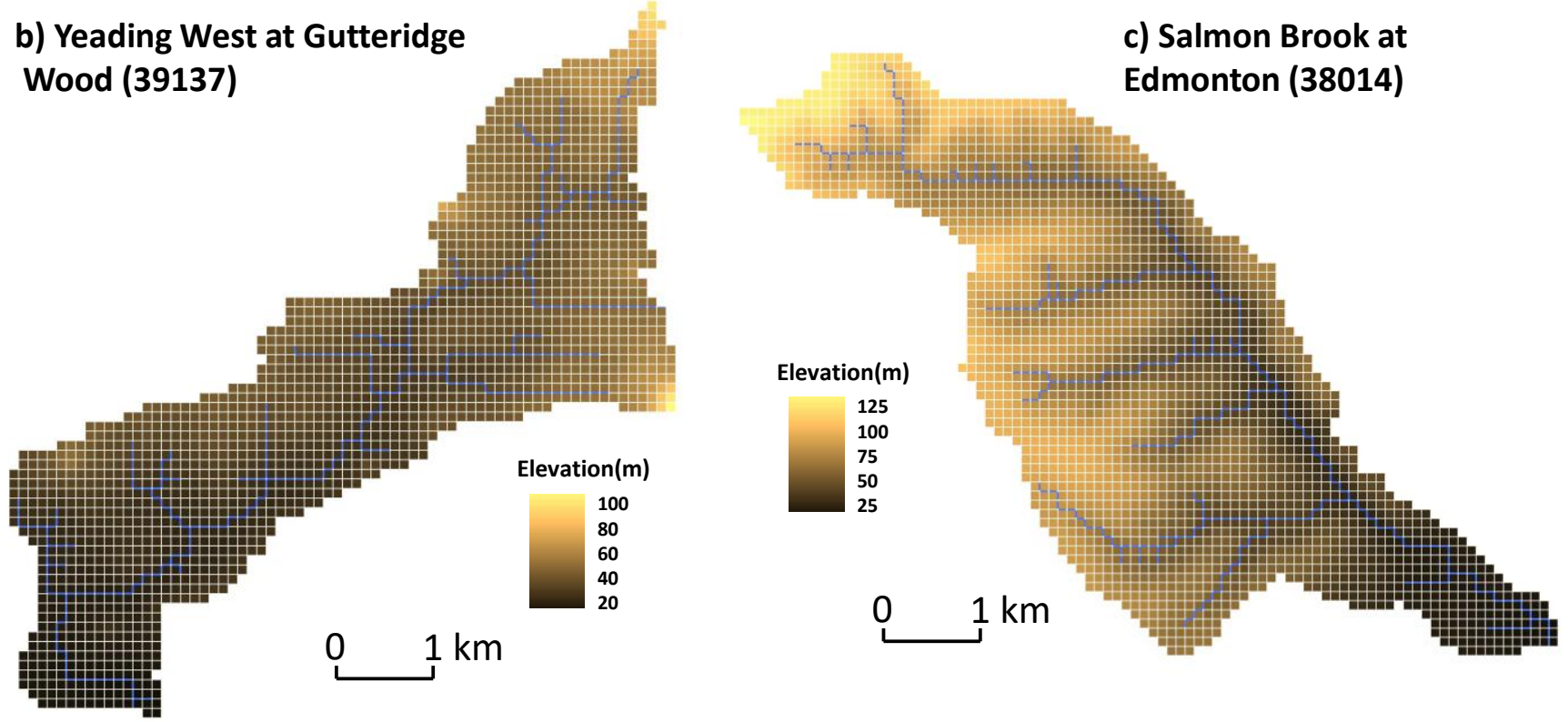

Fig. A.2 Shetran grid network, elevations, and river channels for the three catchments for which hydrological modelling was carried out. 
Table A.4 Vegetation parameters in pervious areas used in the Shetran simulations. The canopy drainage parameter, $C_{k}$, is the rate of drainage when the canopy is at its storage capacity and $C_{b}$ is used in an exponential function to describe how the drainage rate falls as the canopy. The actual/potential evaporation is the value at field capacity, in the model it decreases with soil moisture tension.

\begin{tabular}{llll}
\hline Parameter & Arable & Forest & Grass \\
\hline Canopy drainage $-\mathrm{C}_{\mathrm{K}}(\mathrm{mm} / \mathrm{s})$ & $1.4 \mathrm{E}-5$ & $1.4 \mathrm{E}-5$ & $1.4 \mathrm{E}-5$ \\
Canopy drainage $-\mathrm{C}_{\mathrm{b}}\left(\mathrm{mm}^{-1}\right)$ & 5.1 & 5.1 & 5.1 \\
Canopy storage $(\mathrm{mm})$ & 1.0 & 5.0 & 1.0 \\
Rooting depth $(\mathrm{m})$ & 0.8 & 2.0 & 1.0 \\
Leaf area index $(-)$ & 2.0 & 5.0 & 3.0 \\
Actual/potential evaporation $(-)$ & 0.8 & 1.0 & 0.8 \\
Strickler overland flow $\left(\mathrm{m}^{1 / 3} \mathrm{~s}^{-1}\right)$ & 1.0 & 0.5 & 1.0 \\
\hline
\end{tabular}

Table A.5 Soil parameters in pervious areas used in the Shetran simulations. $\mathrm{K}_{\text {sat }}$ is the saturated conductivity which has been calibrated for the surface soil in each catchment. The remaining parameters were not calibrated.

\begin{tabular}{llllll}
\hline Parameter & $\mathbf{2 3 0 1 6}$ & $\mathbf{2 3 0 1 6}$ & $\mathbf{3 8 0 1 4}$ & $\mathbf{3 8 0 1 4}$ & $\begin{array}{l}\mathbf{3 9 1 3 7} \\
\end{array}$ \\
& $\begin{array}{l}\text { Surface } \\
\text { Soil }\end{array}$ & Sub Soil & $\begin{array}{l}\text { Surface } \\
\text { Soil }\end{array}$ & $\begin{array}{l}\text { Sub Soil } \\
\text { a }\end{array}$ & $\begin{array}{l}\text { Surface } \\
\text { Soil }^{\mathbf{b}}\end{array}$ \\
\hline $\mathrm{K}_{\text {sat }}(\mathrm{m} /$ day) & 30.0 & 1.0 & 50.0 & 2.0 & 6.0 \\
Saturated water content $(-)$ & 0.403 & 0.403 & 0.403 & 0.403 & 0.439 \\
Residual moisture content $(-)$ & 0.025 & 0.025 & 0.025 & 0.025 & 0.010 \\
Van Genuchten alpha $\left(\mathrm{m}^{-1}\right)$ & 3.83 & 3.83 & 3.83 & 3.83 & 3.14 \\
Van Genuchten $\mathrm{n}(-)$ & 1.37 & 1.37 & 1.37 & 1.37 & 1.18 \\
Depth at base of layer $(\mathrm{m})$ & 0.4 & 2.0 & 0.6 & 1.4 & 1.0 \\
\hline
\end{tabular}

a $36 \%$ of the 38014 catchment has an active sub soil

${ }^{b}$ in catchment 39137 there is no active sub soil 